NBER WORKING PAPER SERIES

\title{
TRADE REFORMS, LABOR REGULATIONS \\ AND LABOR-DEMAND ELASTICITIES: EMPIRICAL EVIDENCE FROM INDIA
}

\author{
Rana Hasan \\ Devashish Mitra \\ K. V. Ramaswamy \\ Working Paper 9879 \\ http://www.nber.org/papers/w9879 \\ NATIONAL BUREAU OF ECONOMIC RESEARCH \\ 1050 Massachusetts Avenue \\ Cambridge, MA 02138 \\ July 2003
}

We are grateful to Rajesh Chadha of the University of Delhi and NCAER (New Delhi) for providing us with advice and data on trade protection statistics for India and to Dan Black, Linda Goldberg, Charles Hulten, Duke Kao, Pravin Krishna, Sang-Hyop Lee, and Tom Prusa for useful comments and discussions. Thanks are also due to Alan Ge for generating a useable format of the Annual Survey of Industry data using PERL. The views expressed herein are those of the authors and not necessarily those of the National Bureau of Economic Research.

(C2003 by Rana Hasan, Devashish Mitra, and K. V. Ramaswamy. All rights reserved. Short sections of text, not to exceed two paragraphs, may be quoted without explicit permission provided that full credit, including (C) notice, is given to the source. 
Trade Reforms, Labor Regulations and Labor-Demand Elasticities: Empirical Evidence from India Rana Hasan, Devashish Mitra, and K. V. Ramaswamy

NBER Working Paper No. 9879

July 2003

JEL No. F1, J3

\section{$\underline{\text { ABSTRACT }}$}

Using industry-level data disaggregated by states, this paper finds a positive impact of trade liberalization on labor-demand elasticities in the Indian manufacturing sector. These elasticities turn out to be negatively related to protection levels that vary across industries and over time. Furthermore, we find that these elasticities are not only higher for Indian states with more flexible labor regulations, they are also impacted to a larger degree by trade reforms. Finally, we find that after the reforms, volatility in productivity and output gets translated into larger wage and employment volatility, theoretically a possible consequence of larger labor-demand elasticities.

Rana Hasan

Asian Development Bank

6 ADB Avenue

Mandaluyong City

Metro Manila 0401, PHILIPPINES and East-West Center (Honolulu, HI)

rhasan@adb.org
Devashish Mitra

Department of Economics

The Maxwell School of

Citizenship \& Public Affairs

Syracuse University

133 Eggers Hall

Syracuse, NY 13244

and NBER

dmitra@maxwell.syr.edu

K.V. Ramaswamy

Indira Gandhi Institute for

Development Research

Gen. A.K. Vaidya Marg

Goregaon (E)

Mumbai 400 065, INDIA

swamy@igidr.ac.in 


\section{Introduction}

Trade reforms, even though considered to be welfare enhancing in the aggregate, do not have a uniform impact on all sections of society. Most trade economists like to think about the impact of these reforms in terms of their consequences for capitalists and workers. For example, in the presence of intersectoral factor mobility, opening up an economy to international trade in goods will help labor and hurt capital or vice versa, depending on whether the country's comparative advantage is in labor- or capital-intensive products. In fact, there is an important, ongoing debate on whether trade hurts or benefits unskilled labor relative to skilled workers (the owners of human capital), to which already many well-known scholars in the area have contributed. ${ }^{1}$

A new aspect of the trade-labor linkage that has received some attention in recent years is the impact of international trade in goods on the own-price elasticity of labor demand. The importance of this element of the labor-market impact of trade was first emphasized by Rodrik (1997). He argues that trade makes the demand for labor more elastic which in turn leads to larger employment and wage shocks as a result of given vertical shifts in the labor-demand curve (arising from shocks to productivity or to output demand). Also, this increase in elasticity leads to the erosion of the bargaining power of labor vis-à-vis capital in the sharing of supernormal profits. And finally, it also results in labor bearing a larger burden of the impact of non-wage labor costs. Thus, through this channel, workers are placed under greater pressure as a result of trade liberalization (see Slaughter (1997) for a detailed discussion of these effects). ${ }^{2}$

Why does an increase in openness lead to an increase in labor-demand elasticity? There are two main channels that Rodrik (1997) points out. Firstly, trade reforms allow cheaper imports of intermediate and capital inputs as well as of semi-finished goods and unassembled parts for

\footnotetext{
${ }^{1}$ Important contributions to the literature on the impact of international trade (and globalization in general) on wages and wage inequality have been made by Borjas and Ramey (1995), Feenstra (2000), Feenstra and Hanson (1996, 1997), Hanson and Harrison (1999), Harrigan (1998), Harrison and Hanson (1999), Haskel and Slaughter (2001), Lawrence and Slaughter (1993), Revenga (1992, 1997), and Slaughter (1999).

${ }^{2}$ In this context, we would also like to point out that this very impact of trade liberalization on labor-demand elasticity will, in periods of sustained productivity growth, lead to higher wage and employment growth than prior to the reforms.
} 
assembly/finishing in the importing country. All these imports are substitutes for the services of domestic labor. Thus substitution possibilities in production increase with the availability of possibly cheaper and a larger variety of inputs.

The second channel works through one of Hicks-Marshallian laws of factor demand which can be stated as follows: "The demand for anything is likely to be more elastic, the more elastic is the demand for any further thing which it contributes to produce" (See Hicks (1963) and Slaughter (2001)). Unlike the first channel, which works through what is often called the "substitution effect", the second channel works through the "scale effect" (see Hamermesh (1993)). It is the derived nature of input demand that drives this effect. More specifically, in the presence of a higher output demand elasticity, a given percentage change in output price, resulting from a change in the wage, will lead to a larger percentage change in the output demand (and thus in the scale of production), which in turn calls for a greater percentage change in employment. Given that trade liberalization leads to the greater availability of substitutes for any product (and thus to greater substitution possibilities in consumption), product-demand elasticity increases $^{3}$ which in turn, as explained above, raises factor-demand elasticities.

The first paper that provides a very systematic and rigorous empirical investigation of the impact of the hypothesized positive effect of trade on labor-demand elasticities is Slaughter (2001). Using four-digit industry-level data for the US for the period 1961-91, he finds mixed support for the hypothesis. While own-price elasticities of the demand for production workers have kept increasing over time, Slaughter finds no such trend for non-production workers. However, he also finds that time, by itself, is a better predictor of these elasticities than his traderelated variables, which lose (retain) explanatory power in the presence of time dummies or a common trend in the case of production (nonproduction) labor. Another paper, by Krishna, Mitra

\footnotetext{
${ }^{3}$ Levinsohn (1993), Harrison (1994) and Krishna and Mitra (1998) show that in Turkey, the Ivory Coast and India respectively, trade reforms resulted in lower price-marginal cost markups which implicitly implies a more elastic product demand curve perceived by individual firms.
} 
and Chinoy (2001), uses plant level data from Turkey to examine the same hypothesis and finds no empirical support for it. ${ }^{4}$

In this paper, using industry-level data disaggregated by 15 major states, we empirically examine the impact of the Indian trade reforms, initiated in 1991, on labor-demand elasticities in the manufacturing sector. The time period spanned by our dataset is $1980-97$ and so we test whether these elasticities were higher in the post-reform period, 1992-97 as compared to the previous period, 1980-91. We also examine whether these elasticities are related to protection measures that vary over time and across industries. As our data are by industry and by state, we investigate whether these elasticities and the changes in them, as a consequence of trade liberalization, vary across states. In particular, India's states differ in terms of the restrictions they place on the firing and hiring of workers. By distinguishing between states with "rigid" and "flexible" labor markets on the basis of such restrictions, we are able to examine the relationships between labor-demand elasticities, trade liberalization, and labor-market rigidity.

We try various specifications - constant-output, constant-capital and partial-adjustment labor-demand models and their various meaningful combinations. Across all these models, there are three robust findings. First, labor-demand elasticities go up after the trade reforms. Second, we find that the higher the protection an industry receives, the lower is its labor-demand elasticity. This empirical regularity seems to hold over time and across industries. And third, states with more flexible labor markets (i.e., states in which there are fewer restrictions on the hiring and firing of labor) not only have a more elastic demand for labor, the impact of trade reforms on their labor-demand elasticity is also greater.

We then go on to actually simulate the effects of these estimated changes in elasticities on wages and employment. These simulations are based on alternative assumed values of laborsupply elasticities. We find that the low initial values of our estimated labor-demand elasticities

\footnotetext{
${ }^{4}$ Maskus and Bohara (1985) use data for one year to see the relationship between labor-demand elasticities and product-demand conditions in US manufacturing.
} 
insulate workers from shocks to labor demand in the pre-reform period, but the substantial increase in these elasticities after the reforms can, under certain conditions, result in a fairly large increase in wage and employment volatility for given volatility in the position of the labordemand function. We also carry out a direct empirical test of this hypothesis. We find some evidence of stronger transformation of volatility in total factor productivity (TFP) and output into that in wage and employment (both in terms of their levels as well as changes) after the reforms.

Thus, we believe, that the contribution of the paper is three-fold. It tests the hypothesized link between trade and labor-demand elasticity for a very large, developing country. This largeness also has the feature of diverse labor institutions/regulations across states. By exploiting this diversity we are able to examine whether the effects of trade reforms on labor-demand elasticities are contingent on the nature of labor-market regulations, making this the first paper that separates the effects of trade reforms and labor regulations and at the same time looks at the interaction between the two. To our knowledge, this paper also provides the first direct test of the hypothesized impact of trade liberalization on the transmission of TFP and output volatility into the labor market.

\section{Indian policy framework}

\subsection{The Trade Reforms in India}

In the 1980 's, India experienced moderate economic growth. However, this growth was accompanied by large macroeconomic imbalances reflected in the rapid rise in the fiscal deficit to GDP ratio, in foreign commercial debt and in the debt service ratio (all these being consequences mainly of fiscal indiscipline). These problems were further accentuated by the Gulf War that drastically raised the price of oil. At this time, the general elections of 1991 brought to power a new government that inherited probably the world's most complex and restrictive trade regime based on a firm belief in export pessimism and in the effectiveness of import substitution. Upon assuming power, this new government approached the International Monetary Fund (IMF) for 
help in solving its external payments problem which by then had assumed crisis-like proportions. The IMF loans came attached with the strong conditionality of major economic reforms which were initiated almost immediately. Given several earlier attempts to avoid IMF loans and the associated conditionalities, the large number of members of the new cabinet who had been cabinet members in past governments with inward-looking trade policies and the heavy reliance on tariffs as a source of revenues, these reforms came as a surprise.

The major trade reform objectives announced by the Indian government in July, 1991 included the removal of most licensing and other non-tariff barriers on all imports of intermediate and capital goods, the broadening and simplification of export incentives, the removal of export restrictions, the elimination of the trade monopolies of the state trading agencies, the simplification of the trade regime, the reduction of tariff levels and their dispersion and the full convertibility of the domestic currency for foreign exchange transactions. Subsequently, the maximum tariff was reduced from 400 percent to 150 percent in July 1991, to 110 percent in February 1992, to 85 percent in February 1993, 64 per cent in February 1994 and to roughly 45 percent by 1997-98. The mean tariff went from 128 percent before July 1991 to 94 percent in February 1992, 71 percent by February 1993, 55 percent in February 1994 and to roughly 35 percent by 1997-98. The standard deviation of tariffs during this period went down from 41 percentage points to roughly $15 .^{5}$ Table 1 provides tariffs and percentage changes in the period 1988-97 for different industries in the Indian manufacturing sector. ${ }^{6}$ We see steady and substantial reductions in tariffs throughout this entire period.

As far as the non-tariff barriers were concerned, prior to 1991, there were quantitative restrictions on 90 percent of the value added in the manufacturing sector. In April 1992, all the twenty six import licensing lists were eliminated. However a "negative list" (from which most

\footnotetext{
5 See Dutt (2003) and Krishna and Mitra (1998).

${ }^{6}$ The construction of these tariff rates is described in Section 4.2.
} 
intermediate and capital goods were excluded) of items, whose imports were prohibited, was introduced, thereby eliminating many of the licensing procedures and discretionary decisions of the previous import regime.

There were also changes in the exchange rate. The Indian Rupee was devalued 20 percent against the US dollar in July 1991 and further devalued in February 1992 when an explicit dual exchange market was introduced. The percentage reduction in tariffs and non-tariff barriers were much greater than the percentage devaluation (and even larger relative to the real exchange rate devaluation on account of fairly high inflation, hitting roughly 14 percent, during the initial years of the reforms). Therefore, the import enhancing effect of the trade reforms should have more than offset the import reducing effect of the exchange rate devaluation.

\subsection{Labor Markets: Regulations and Rigidity}

While a comprehensive review of India's labor markets is beyond the scope of this paper some key features of labor regulations in India and their implications for labor-market rigidity in the manufacturing sector are worth noting. ${ }^{7}$ First, legislative authority over labor issues falls with both the central (federal) government as well as individual state governments so that the latter have the authority to amend central legislations or to introduce subsidiary legislations. In addition, the enforcement of many labor regulations, even those enacted by the central government, lies with the state governments. Both factors suggest that there may be considerable variation in labor regulations and/or their enforcement across India's states.

Second, a number of pro-reform policymakers and analysts believe that India's labor laws have made labor markets in the manufacturing sector rigid in the sense of placing serious impediments in the hiring and firing of workers. As per the Industrial Disputes Act (IDA), for example, it is necessary for firms employing more than 100 workers to obtain the permission of

\footnotetext{
7 See Dutt (2003) for a more detailed discussion of India's labor-market regulations.
} 
state governments in order to retrench or layoff workers. ${ }^{8,}$ While the IDA does not prohibit retrenchments, critics of the act argue that it is difficult to carry them out. Datta-Chaudhuri (1996) argues, for example, that states have often been unwilling to grant permission to retrench, perhaps for reasons of political expediency. Provisions for job security among individual workers come additionally from the operation of the Industrial Employment (Standing Orders) Act. This act requires all employers with 100 or more workers (50 in certain states) to specify to workers the terms and conditions of their employment. While the Act seeks to make labor contracts complete, fair, and legally binding it has some features which may interfere with quick adjustments to changing conditions. In particular, worker consent is required in order to modify job descriptions or move workers from one plant to another in response to changing market conditions. The problem, according to some analysts, is that the workings of India's Trade Union Act (TUA) make it difficult to obtain worker consent. While the TUA allows any seven workers in an enterprise to form and register a trade union, it has no provisions for union recognition (for example, via a secret ballot). The result, according to Anant (2000), has been multiple unions (within the same establishment) with rivalries common across unions so that a requirement of worker consent for enacting changes "can become one of consensus amongst all unions and groups, a virtual impossibility” (page 251).

It is important to note, however, that not all analysts agree that India's labor laws have made for a rigid labor market. In particular, an important counter-argument to the views expressed above is that India's labor regulations relating to job-security have been either ignored (see Nagaraj (2002)) or circumvented through the increased usage of temporary or contract labor

\footnotetext{
${ }^{8}$ Until 1976, the provisions of the IDA were fairly uncontroversial. The IDA allowed firms to layoff or retrench workers as per economic circumstances as long as certain requirements such as the provision of sufficient notice, severance payments, and the order of retrenchment among workers (last in first out) were met. An amendment in 1976 (the introduction of Chapter VB), however, made it compulsory for employers with more than 300 workers to seek the prior approval of the appropriate government before workers could be dismissed. A further amendment in 1982 widened the scope of this regulation by making it applicable to employers with 100 workers or more.

${ }^{9}$ The term layoff refers to a temporary or seasonal dismissal of a group of workers due to slackness of current demand. Retrenchments, on the other hand, denote permanent dismissals of a group of workers. Both terms may be distinguished from "termination" which refers to separation of an individual from his or her job.
} 
(see, in particular, Datta (2003) and Ramaswamy (2003)). ${ }^{10}$ Ultimately, whether India's labor laws have created significant rigidities in labor markets or not is an empirical issue.

\section{Theory}

\subsection{Constant-Output Labor-Demand Elasticity, Trade Liberalization and Labor}

\section{Regulations}

Let us consider the following cost minimization problem of a representative firm:

$$
\operatorname{Min}_{K, L, M} r K+w L+m M \text { subject to } Q=F(K, L, M)
$$

where $r, w$ and $m$ are the user cost of capital, the wage rate and the materials price respectively, while $K, L$ and $M$ represent capital, labor and materials and $Q$ is output. It must be noted that the above minimization can be written in terms of nominal factor prices or equivalently in terms of real factor prices (in units of the output), as with the former we just have a scaled up minimand of the latter. ${ }^{11}$

The above optimization yields the following conditional labor-demand function and constant-output labor-demand elasticity respectively:

$$
L=L(w, r, m, Q), \quad\left|\frac{\partial \ln L}{\partial \ln w}\right|_{Q \text { const. }}=\left(1-S_{L}\right) \sigma
$$

where $\sigma$ is the elasticity of substitution of labor with respect to other inputs and $s_{L}$ is the share of labor in overall output. Note that this formula is based on the assumption of constant returns to scale and perfect competition. ${ }^{12}$ If our production function is Cobb-Douglas, given by $Q=K^{\alpha} L^{\beta} M^{\gamma}$ (and not necessarily constant returns to scale, and if the market is not necessarily perfectly competitive), the labor-demand function can be written as:

\footnotetext{
${ }^{10}$ Our measure of employment of production labor includes, permanent, temporary and contract.

${ }^{11}$ If $P$ is the product price, then minimizing cost in terms of given real factor prices is just minimizing $(1 / P)$ times what would have been minimized if cost had been defined in terms of nominal factor prices. Thus, the elasticities of the constant-output labor-demand function with respect to the nominal and real factor prices should be the same.

${ }^{12}$ The assumptions of constant returns and perfect competition ensure that the elasticity of output with respect to any factor equals its share in output and the rewards to different factors exhaust the total output.
} 


$$
\ln L=\text { const. }-\frac{\alpha+\gamma}{\alpha+\beta+\gamma} \ln w+\frac{\alpha}{\alpha+\beta+\gamma} \ln r+\frac{\gamma}{\alpha+\beta+\gamma} \ln m+\frac{1}{\alpha+\beta+\gamma} \ln Q
$$

Thus, the labor-demand elasticity is $\left|\frac{\partial \ln L}{\partial \ln w}\right|_{Q \text { const. }}=\frac{\alpha+\gamma}{\alpha+\beta+\gamma}$. Under constant returns to scale $(\alpha+\beta+\gamma=1)$, it is easy to see that the above formula becomes $\left|\frac{\partial \ln L}{\partial \ln w}\right|_{Q \text { const. }}=(1-\beta)$. Under the further assumption of perfect competition, we have $s_{L}=\beta$ (i.e., the share of labor in output equals the elasticity of output with respect to labor in the firm's production function). Furthermore, $\sigma=1$ under Cobb-Douglas. Thus, we can see how our elasticity formula under a Cobb-Douglas technology is related to the earlier formula in equation (2).

Thus, what we learn from all of the above is that the wage elasticity of the constantoutput labor demand is increasing in the elasticity of substitution of labor with respect to other inputs and decreasing with respect to the elasticity of output with respect to labor (decreasing in labor's output share under perfect competition and constant returns to scale). Trade liberalization facilitates the import of larger varieties of inputs and therefore, increases the elasticity of substitution of labor with respect to all other inputs. In other words, new imported material and capital inputs can substitute the services of domestic workers. Moreover, if we consider the overall production function of a firm as an aggregation of production functions for different stages of production, then trade liberalization, by facilitating imports of semi-finished and unassembled products (to be finished and assembled in the home country) will reduce the share of labor in the overall sales of the industry. Thus, both the increase in $\sigma$ and the fall in $s_{L}$ work in the same direction towards raising the labor-demand elasticity.

Another issue we will focus on in this paper is the effect of labor regulations. As noted in Section 2.2 India's labor laws are widely believed to have led to restrictions on the hiring and firing of workers, thereby limiting substitution possibilities in response to changes in factor prices. Under such conditions, there is going to be a difference between the "effective" 
production function and the "ideal" production function (given just by the available technological know-how) faced by firms, the elasticity of substitution $\sigma$ being lower for the former than for the latter.

\subsection{Unconstrained and Capital-Constrained Labor-Demand Functions: Imperfect versus Perfect Competition, Real- versus Nominal-Wage Elasticities and the Impact of Trade Reforms and Labor Regulations}

Now, we focus on the profit maximization problem of the firm in which the output is not taken as given but is determined endogenously, given factor prices. We first work with a model of monopolistic competition, where each firm faces its less than infinitely elastic demand curve and where there is assumed to be no strategic interaction between firms. ${ }^{13}$ Thus a representative firm in an industry is assumed to face an inverse demand curve of the type:

$$
P=\bar{\theta} Q^{-1 / \varepsilon}
$$

where $P$ and $Q$ are the price and quantity of the product, $\varepsilon$ is the constant product demand elasticity faced by a representative firm and $\bar{P}$ denotes the industry average price. ${ }^{14}$ The production function is assumed to be of a Cobb-Douglas type and is given by

$$
Q=K^{\alpha} L^{\beta} M^{\gamma}
$$

where $K, L$ and $M$ are the capital, labor and material inputs used by this representative firm.

The firm is assumed to face infinitely elastic factor supplies, i.e., it takes factor prices as given. Partially differentiating profits with respect to the $l$ th input and equating it to zero gives us the following first order condition:

$$
\theta \bar{P} Q^{1-1 / \varepsilon}\left(1-\frac{1}{\varepsilon}\right) \alpha K^{-1}=r, \quad \theta \bar{P} Q^{1-1 / \varepsilon}\left(1-\frac{1}{\varepsilon}\right) \beta L^{-1}=r, \quad \theta \bar{P} Q^{1-1 / \varepsilon}\left(1-\frac{1}{\varepsilon}\right) \gamma M^{-1}=m
$$

\footnotetext{
${ }^{13}$ This approximates a situation in which there are a large number of varieties and each firm is an infinitesimal player but has some power over the pricing of it product (variety).

${ }^{14}$ In an industry with a continuum of firms, $\bar{P}$ approximates the price index of close substitutes.
} 
where $r, w$ and $m$ denote the nominal user cost of capital, the wage rate and material price respectively. From the above three first order conditions, we get the following labor-demand function:

$$
\ln L=\delta_{0}+\delta_{w} \ln (w / \bar{P})+\delta_{r} \ln (r / \bar{P})+\delta_{m} \ln (m / \bar{P})
$$

which is a function in terms of the variables taken as exogenous by the firm - factor prices and the industry average price. If we are looking at industry employment with $n$ identical firms, then it is just $n$ times the firm employment at any given vector of real factor prices and so in the log version above the extra "In $n$ " gets absorbed in the constant term. All the coefficients in the above equation are all functions of $\varepsilon$. The own price elasticity of labor demand (with respect to the industry product wage) and its partial derivative with respect to the product demand elasticity are given by:

$$
\left|\frac{\partial \ln L}{\partial \ln (w / \bar{P})}\right|=\left|\delta_{w}\right|=\frac{\left[1-\left(1-\frac{1}{\varepsilon}\right)(\alpha+\gamma)\right]}{\left[1-\left(1-\frac{1}{\varepsilon}\right)(\alpha+\beta+\gamma)\right]}, \frac{\partial\left|\delta_{w}\right|}{\partial \varepsilon}=\frac{\beta}{\varepsilon^{2}\left[1-\left(1-\frac{1}{\varepsilon}\right)(\alpha+\beta+\gamma)\right]^{2}}>0
$$

Thus, (the absolute value of) labor-demand elasticity is increasing in (the absolute value of) product demand elasticity. ${ }^{15}$

If capital is held fixed, then we work on the basis of only two first order conditions, namely, those for labor and materials and the labor-demand elasticity then gets modified to

$$
\left|\frac{\partial \ln L}{\partial \ln (w / \bar{P})}\right|=\frac{\left[1-\left(1-\frac{1}{\varepsilon}\right) \gamma\right]}{\left[1-\left(1-\frac{1}{\varepsilon}\right)(\beta+\gamma)\right]}
$$

which clearly again is increasing in $\varepsilon$.

\footnotetext{
${ }^{15}$ Note that we are defining our labor-demand elasticities in terms of absolute values throughout. The values with the modulus (absolute value) taken out are negative.
} 
Now let us instead look at a price taking (perfectly competitive) firm in an industry with perfect substitutes (homogeneous commodity). Each firm has to sell the product at the industry price $\bar{P}$ and the firm's profit maximization problem can be written as:

$$
\operatorname{Max}_{K, L, M} \bar{P} K^{\alpha} L^{\beta} M^{\gamma}-r K-w L-m M
$$

which gives us a labor-demand function such that the log of labor demanded is again linear in the logs of $w / \bar{P}, m / \bar{P}$ and $r / \bar{P} \cdot{ }^{16}$ Again in an industry with symmetric firms, the difference between the industry and firm log labor demanded (as a function of the logs of real factor rewards) is just in the constant term. The unconstrained elasticity of the demand for labor with respect to the product (real) wage and the constant-capital elasticity (conditional on capital) are given respectively by:

$$
\left|\frac{\partial \ln L}{\partial \ln (w / \bar{P})}\right|=\frac{[1-(\alpha+\gamma)]}{[1-(\alpha+\beta+\gamma)]},\left|\frac{\partial \ln L}{\partial \ln (w / \bar{P})}\right|_{K=\bar{K}}=\frac{[1-\gamma]}{[1-(\beta+\gamma)]}
$$

We can see the two elasticities in (11) are independent of the product demand elasticity and they only depend on the elasticities of output with respect to the variable factors. When we depart from the Cobb-Douglas specification, they will additionally depend on the elasticity of substitution $\sigma$. Thus, while the elasticity of labor demand with respect to real product wage depends on product demand elasticity in the case of an imperfectly competitive industry, it is not so in the case of a perfectly competitive industry. However, it must be noted that from the point of view of the industry as a whole, the price $\bar{P}$ is endogenous. Given the product demand curve, this price will be endogenous to nominal factor rewards, $w, r$ and $m$ as the output supply for any given output price will depend on these nominal factor prices. Taking this endogeneity into account, we can easily calculate the elasticity of labor demand with respect to the nominal wage rate. We will show that this elasticity will depend on the product demand elasticity even under

\footnotetext{
${ }^{16}$ The above maximization problem is defined only if $\alpha+\beta+\gamma \leq 1$. Also, the size of the firm at any given price is undefined if $\alpha+\beta+\gamma=1$. This is not really a problem under CRS as the conditions of the equality of price to average cost (in long-run equilibrium), the equality of market demand to supply and identical firms will determine firm size in equilibrium.
} 
price-taking behavior by firms in the product market. This means that under imperfect competition, there is an additional positive effect of product demand elasticity, when the elasticity of labor demand is calculated with respect nominal wages instead of real wages. We first focus here on the elasticity conditional on capital. Here we can write the total derivative of the log of labor with respect to the log of nominal wage as follows:

$$
\left.\frac{d \ln L}{d \ln w}\right|_{K=\bar{K}}=\left.\frac{\partial \ln L}{\partial \ln w}\right|_{K=\bar{K}}+\left.\left(\left.\frac{\partial \ln L}{\partial \ln p}\right|_{K=\bar{K}}\right) \frac{d \ln p}{d \ln w}\right|_{K=\bar{K}}
$$

Noting that $\left.\frac{\partial \ln L}{\partial \ln (w / p)}\right|_{K=\bar{K}}=\frac{-[1-\gamma]}{[1-(\beta+\gamma)]},\left.\frac{\partial \ln L}{\partial \ln (m / p)}\right|_{K=\bar{K}}=\frac{-\gamma}{[1-(\beta+\gamma)]}$, we have:

$$
\begin{aligned}
\left.\frac{d \ln L}{d \ln w}\right|_{K=\bar{K}} & =-\frac{-[1-\gamma]}{[1-(\beta+\gamma)]}+\left.\left[\frac{[1-\gamma]}{[1-(\beta+\gamma)]}+\frac{\gamma}{[1-(\beta+\gamma)]}\right] \frac{d \ln p}{d \ln w}\right|_{K=\bar{K}} \\
& =\frac{-[1-\gamma]}{[1-(\beta+\gamma)]}+\left.\frac{1}{[1-(\beta+\gamma)]} \frac{d \ln p}{d \ln w}\right|_{K=\bar{K}}
\end{aligned}
$$

Equating output demand to its supply and taking further derivatives, we have

$$
\begin{aligned}
& d \ln Q^{D}=d \ln Q^{S} \\
& \Rightarrow \frac{\partial \ln Q^{D}}{\partial \ln p} \cdot \frac{d \ln p}{d \ln w}=\frac{\partial \ln Q^{S}}{\partial \ln p} \cdot \frac{d \ln p}{d \ln w}+\frac{\partial \ln Q^{S}}{\partial \ln L} \cdot \frac{\partial \ln L}{\partial \ln w}+\frac{\partial \ln Q^{S}}{\partial \ln M} \cdot \frac{\partial \ln M}{\partial \ln w} \\
& \Rightarrow-\varepsilon^{D} \frac{d \ln p}{d \ln w}=\varepsilon^{S} \cdot \frac{d \ln p}{d \ln w}+\beta \cdot \frac{-[1-\gamma]}{[1-(\beta+\gamma)]}+\gamma \cdot \frac{-\gamma}{[1-(\beta+\gamma)]} \\
& \Rightarrow \frac{d \ln p}{d \ln w}=\frac{\beta(1-\gamma)+\gamma^{2}}{[1-(\beta+\gamma)]\left(\varepsilon^{D}+\varepsilon^{S}\right)}
\end{aligned}
$$

which gives us the labor-demand elasticity with respect to the nominal wage and its derivative with respect to the product-demand elasticity as follows:

$\left|\frac{d \ln L}{d \ln w}\right|_{K=\bar{K}}=\frac{[1-\gamma]}{[1-(\beta+\gamma)]}-\frac{\beta(1-\gamma)+\gamma^{2}}{[1-(\beta+\gamma)]^{2}\left(\varepsilon^{D}+\varepsilon^{S}\right)}, \frac{\partial\left|\frac{d \ln L}{d \ln w}\right|_{K=\bar{K}}}{\partial \varepsilon^{D}}=\frac{\beta(1-\gamma)+\gamma^{2}}{[1-(\beta+\gamma)]^{2}\left(\varepsilon^{D}+\varepsilon^{S}\right)^{2}}>0$ 
We finally look at the case of perfect competition and constant returns to scale with all factors variable, where the unconditional labor-demand elasticity (from profit maximization), after allowing demand to equal supply and price to equal average cost is given by

$$
\left|\frac{d \ln L}{d \ln w}\right|=\left|\frac{d \ln L}{d \ln w}\right|_{Q \text { const. }}+s_{L} \varepsilon^{D}=\left(1-s_{L}\right) \sigma+s_{L} \varepsilon^{D}
$$

Thus the elasticity of labor demand with respect to the nominal wage is a weighted average of the elasticity of substitution and the elasticity of demand, the weights respectively being the share of factors other than labor and that of labor respectively. As explained before, the elasticity of substitution goes up due to trade liberalization. Also, the increased availability of substitutes for the final good will make the output demand also more elastic. Thus for a fixed share of labor in output, as a consequence of liberalization, both the product demand elasticity and the elasticity of substitution between factor inputs will move the labor-demand elasticity in the upward direction. However, as explained in the case of the constant-output labor-demand elasticity, the share of labor in total output may also go down, which can make the direction of movement of this unconstrained (or even the capital-constrained) labor-demand elasticity ambiguous. This makes empirical work in this area all the more important. And, finally as explained before, the labordemand elasticity will also be determined by labor regulations through their impact on the effective $\sigma$.

\subsection{Adjustment Costs and the Dynamic Labor-Demand Function}

We now know how trade liberalization could make labor demand more elastic. However, what we have focused on so far is the firm's ideal labor demand and the actual labor demand may be different from the ideal due to the presence of rigidities and frictions in the labor market. ${ }^{18}$ So we

\footnotetext{
${ }^{17}$ See Hamermesh (1993).

${ }^{18}$ It needs to be noted, as argued in section 3.1, that even what we call the "ideal" (or "long-run") labor-demand function here is not truly "ideal" as labor regulations may render substitution elasticities different from the ones purely
} 
introduce labor-market frictions in this subsection. Let us denote the actual labor demand (in log terms) by $l^{A}$ and the ideal labor demand (again in $\operatorname{logs}$ ) by $l$. We denote lagged employment by $l_{-1}^{A}$. Let $0<\lambda<1$ denote the extent of labor-market frictions that act as impediments in the hiring and firing of labor. We then write the actual labor demand as a weighted average of the ideal labor demand and the lagged level of employment, the relative weight on lagged employment being increasing in labor-market rigidity. Therefore, our actual labor-demand function can be written as

$$
l^{A}=\lambda l_{-1}^{A}+(1-\lambda) l \quad \Leftrightarrow \quad l^{A}=l_{-1}^{A}+(1-\lambda)\left(l-l_{-1}^{A}\right)
$$

This equation represents a partial adjustment model, $1-\lambda$ being the speed of adjustment (which is negatively related to labor-market rigidity). The model suggests that only a part of the gap between desired and actual employment is closed every period and the proportion of the gap closed is increasing in labor-market flexibility. After plugging in the equation for our ideal labor demand into the actual labor-demand equation, we have

$$
l^{A}=\lambda l_{-1}^{A}+(1-\lambda)\left(\delta_{0}+\delta_{w} \ln w+\delta_{r} \ln r+\delta_{m} \ln m\right)
$$

where $l=\delta_{0}+\delta_{w} \ln w+\delta_{r} \ln r+\delta_{m} \ln m$ stands for ideal labor-demand function. Depending on the context, in place of this unconstrained demand function, we can substitute the conditional (on output or capital) labor-demand function (as the "ideal" labor demand). As we can clearly see, even when we are estimating the actual labor-demand function, for given $\lambda$ the elasticity of this actual labor demanded should increase with trade liberalization and decrease with the restrictiveness of labor regulations. We will from now on call $(1-\lambda) \delta_{\mathrm{w}}$ the short-run elasticity of labor demand and $\delta_{\mathrm{w}}$, irrespective of whether we are using the unconstrained or the capital/output-constrained labor demand as the ideal labor demand within the overall actual, dynamic labor-demand function.

based on technological know-how. Thus, even the "ideal" labor demand is going to be based on what we call the "effective" and not the "ideal" production function in section 3.1. 
It is important to note that restrictive labor laws are not the only reason for deviations between actual and ideal labor demand. For example, since layoffs may reduce efficiency by lowering the morale of remaining employees firms may respond by adjusting labor more slowly than otherwise (Hamermesh (1993)). Additionally, given that hiring workers is a costly process involving search costs, training costs, and possibly disruptions in production as the flow of work across plants is reorganized - firms may "hoard labor" in response to what may only be a temporary decline in product demand. Actual employment may therefore exhibit stickiness even in the absence of any regulatory restriction on layoffs. Moreover, regulatory restrictions may interact with these other factors in complex ways. While more restrictive labor laws make the " $\lambda$ " larger by introducing impediments in the hiring and firing of labor, they may generate some offsetting effects on the value of $\lambda$. In particular, more restrictive labor laws may influence negatively the overall investment climate. A deterioration of the latter could lower $\lambda$ by reducing labor hoarding, investments in human capital such as expenditure on worker training, and job turnover. $^{19}$

\subsection{Labor-Demand Elasticity and Wage and Employment Volatility}

Let the following represent inverse labor-demand and supply functions:

$$
\ln w_{t}=\ln A_{t}-\left(1 / \eta^{D}\right) \ln L_{t}, \ln w_{t}=\left(1 / \eta^{S}\right) \ln L_{t}
$$

where $\eta^{D}$ and $\eta^{S}$ represent the absolute values of labor-demand and labor-supply elasticities respectively. $A_{\mathrm{t}}$ stands for the vertical intercept of the inverse labor-demand function and changes in it reflect changes in labor productivity or in output demand conditions. In labor-market equilibrium, we have

\footnotetext{
19 As will be pointed out in Section 4.2 below, Indian states with flexible labor markets tend to be rated by managers as having a good investment climate. These states also tend to be India's most dynamic and fast growing states (World Bank (2003)). Thus expectations of better prospects for recovery and growth in such states are more likely to lead to labor hoarding by firms in response to temporary demand shocks. Since these firms may also invest more in worker training and require more skilled workers, they may have greater incentives to retain workers through temporary downturns.
} 


$$
\ln w_{t}^{*}=\frac{\left(1 / \eta^{S}\right) \ln A_{t}}{\left(1 / \eta^{D}\right)+\left(1 / \eta^{S}\right)}, \ln L_{t}^{*}=\frac{\ln A_{t}}{\left(1 / \eta^{D}\right)+\left(1 / \eta^{S}\right)}
$$

Thus, we have

$$
\frac{d \ln w_{t}^{*}}{d \ln A_{t}}=\frac{\left(1 / \eta^{S}\right)}{\left(1 / \eta^{D}\right)+\left(1 / \eta^{S}\right)}, \frac{d \ln L_{t}^{*}}{d \ln A_{t}}=\frac{1}{\left(1 / \eta^{D}\right)+\left(1 / \eta^{S}\right)}
$$

These derivatives in (21) measure the proportion of the volatility of $A_{t}$ that gets transmitted as wage and employment volatility and so measure the strength of this transmission. Both these derivatives are positively related to $\eta^{D}$. Thus an increase in the labor-demand elasticity will mean that for a given percentage increase (or decrease) in $A_{t}$, we get a larger percentage increase (or decrease) in wage and employment. Thus, for a given volatility in $A_{t}$, we will get bigger volatility in wage and employment. However, it also means that during periods of sustained growth in $A_{t}$, we also get larger growth rates of wage and employment arising from a given growth rate of $A_{t .}$ Thus trade reforms can lead to bigger volatility in wages and employment. However, it can possibly also lead to faster growth in wages and employment if total factor productivity is growing at a constant positive rate.

\section{Estimation Issues and Data}

\subsection{Estimation Issues}

Obtaining estimates of the labor-demand function are central to determining how trade liberalization and labor regulations have affected workers. In what follows we describe our specifications of the labor-demand function and discuss various estimation related issues.

We estimate two types of labor-demand equations: one which is conditional on output and another which is conditional on capital. As pointed out in Section 3, the former allows us to infer the effect of trade liberalization and labor-market regulations on labor-demand elasticity via their impact on substitution possibilities in production while the latter captures additionally the 
effect of trade liberalization on labor-demand elasticity via its impact on product demand elasticities. ${ }^{20}$ The output-constrained labor-demand function takes the form:

$$
\begin{aligned}
\ln L_{i s t} & =\lambda \ln L_{i s t-1}+\sum_{f} \delta_{f}^{*} \ln f_{i s t}+\delta_{T P}^{*} T P_{i t}+\delta_{F L E X}^{*} F L E X_{s}+\sum_{f} \delta_{f T P}^{*}\left(\ln f_{i s t}\right) T P_{i t}+ \\
& +\sum_{f} \delta_{f F L E X}^{*}\left(\ln f_{i s t}\right) F L E X_{s}+\delta_{Q}^{*} \ln Q_{i s t}+\sum_{t} \phi_{t} Y_{t}+\mu_{i s}+\varepsilon_{i s t}
\end{aligned}
$$

where $L$ denotes the employment of production workers in industry $i$, state $s$ and year $t, f$ represents factor prices (wages, $w$; user cost of capital, $r$; and material prices, $m$ in terms of the notation of Section 3 above $)^{21}$, TP stands for trade policy and may vary by industry and over time, FLEX represents labor-market flexibility across states, $Q$ is output, $Y$ represents year dummies, $\mu_{i s}$ is an industry-state effect, and $\varepsilon_{i s t}$ is a white noise error term. The effects of trade liberalization and labor-market flexibility on labor-demand elasticity are captured by the coefficients of the interaction terms involving $w$ and $T P$ and $w$ and FLEX, respectively. ${ }^{22}$ The specification of the capital-constrained labor-demand function is identical other than (i) the substitution of $\ln Q$ with $\ln K$ and (ii) omission of all terms involving the user cost of capital from the right hand side of equation 22. Of course, the parameters of the capital-constrained labor-demand function have different interpretations. We also estimate the specification that does not allow for any adjustment costs (i.e., the restricted model with $\lambda=0$ which is a static labor-demand function).

\footnotetext{
${ }^{20}$ Note, however, that the elasticity of labor demand derived from the capital-constrained labor-demand function will not incorporate substitution possibilities between labor and capital.

21 Two factors led us to use nominal factor prices rather than real product factor prices (i.e., factor prices deflated by product prices) in estimation. First, product prices are endogenous at the industry level. Thus using nominal factor prices can alleviate endogeneity concerns. Second, as explained in Section 3.2, the elasticity of labor demand with respect to the real product wage will not depend on product demand elasticity if an industry is competitive. To make sure that we do not miss out on the effects of changes in product demand elasticities on labor-demand elasticities we use nominal factor prices. It may be noted, however, that results using real product factor prices were very similar to those based on nominal factor prices.

22 Thus if $T P$ is measured in terms of tariff rates then a positive estimate of $\delta_{w T P}^{*}$ (i.e., $[1-\lambda] \delta_{w T P}$ in terms of the notation of equation 18) implies that tariff reductions are associated with an increase in labor-demand elasticity. Similarly, if $F L E X=1$ if the labor market is flexible and zero otherwise, then a negative value for $\delta_{w F L E X}^{*}$ implies that labor-market flexibility is associated with an increase in labor-demand elasticity.
} 
There are several issues pertaining to specification that are worth highlighting. First, our choice of estimating conditional labor-demand functions is practical. Shocks to product demand are likely to move labor demand for an industry in the same direction. Estimating a labordemand equation without controlling for these shocks would then result in biased parameter estimates as the resulting shocks to labor demand trace out the labor-supply curve. The inclusion of output or capital in the conditional labor-demand functions is likely to control for at least a part of the product demand shocks thereby alleviating biases on this account.

Second, in order to interpret the estimated coefficients of equation 22 (or its capital based analogue) as parameters of the labor-demand function we need to assume that the supply of labor to each industry-state unit is perfectly elastic so that wages are exogenous. ${ }^{23}$ This assumption may seem strong given that we do not have firm level data. However, there are several mitigating factors in our application which serve to make this assumption a plausible one. In the first place, our unit of analysis is an industry-state combination where our data pertain to 18 manufacturing industries disaggregated by 15 of India's major states. This is a much higher level of disaggregation in comparison to studies which use either manufacturing wide data or even economy-wide industry level data. In addition, employment in the formal manufacturing sector, from which our data comes, is estimated to be less than 10 percent of total non-agricultural employment (Ghose (1999)). This, combined with the pressures of rural-urban migration and the existence of considerable open and disguised unemployment in urban areas (Kundu and Gupta (1996)), makes it likely that individual state-industry units will face a relatively elastic labor supply. $^{24}$

\footnotetext{
23 An alternative would be to allow wages to be endogenous and use instruments for these. In the absence of any plausible instruments for wages in our dataset, we tried using lagged wages as instruments but the results were quite poor. In particular, estimated wage elasticities were often positive. As a result we decided against instrumenting wages.

24 Indeed, calculations using individual level data from the National Sample Survey data for 1993 suggest that the pool of informal sector workers in manufacturing itself is large enough to keep labor supply to a state-industry unit in the formal sector fairly flat. In the Indian context, it is probably fair to assume that the bulk of self-employed workers in manufacturing would prefer to work as wage and salaried workers if they could (see, for example, Ghosh (1999) on this
} 
Third, relegating the industry-state effects, $\mu_{i s}$, to the error term and estimating labordemand functions by OLS is very likely to lead to unsatisfactory estimates. ${ }^{25}$ Since $\ln L_{i t}$ is a function of $\mu_{i s}$, the lagged dependent variable, $\ln L_{i t-1}$, will also be a function of $\mu_{i s}$ thereby rendering OLS biased and inconsistent. In addition, unobserved industry-state characteristics may well be correlated with one or more of the other regressors. The usual solution to the resulting omitted variable bias plaguing the OLS estimator - employing the within or fixed effects estimator - is not a satisfactory solution in our case. This is because the within transformation will introduce a negative correlation of order 1/T between the transformed error and the transformed $\ln L_{i t-1}$ term (Hsiao (1986)). For those regressions which involve small $\mathrm{T}$ (less than 10 in some of the cases we consider below), the resulting bias can be large.

While the fixed effects estimates can still be informative ${ }^{26}$ and we present these below, we use the generalized method of moments (GMM) IV estimator of Arellano and Bond (1991) in order to obtain consistent and efficient estimates of the labor-demand equation. The GMM-IV estimator involves (i) carrying out a first difference (FD) transformation of equation 22 (and its capital based analogue) to get rid of the correlation between $\mu_{i s}$ and $\ln L_{i t-1}$ (and other right-handside variables); and (ii) using an instrument for the lagged, differenced employment term, $\ln L_{i t-1}-$ $\ln L_{i t-2}$ since it is correlated with the transformed error term, $\varepsilon_{i s t}-\varepsilon_{i s t-1}$. As long as the $\varepsilon_{i s t}$ are not serially correlated, a natural choice for an instrument is $\ln L_{i t-2}$. Additional instruments can be obtained by utilizing the orthogonality conditions existing between the further lags of employment and $\varepsilon_{i s t}$. Estimation is carried out using the one-step GMM estimator of Arellano

point). In urban areas alone, self-employed workers are $73 \%$ of the number of total wage and salaried workers in manufacturing. Since the latter include wage and salaried workers in the formal and informal sectors, the $73 \%$ figure is probably a lower bound on the ratio of self-employed workers in manufacturing to wage and salaried workers in formal manufacturing. Introducing the rural self-employed in manufacturing into the equation would likely drive the ratio of self-employed to wage and salaried workers in formal manufacturing to well over 1.

25 Although we are using notation from the output-constrained labor-demand function of equation 22 , the arguments apply equally to the capital-constrained labor-demand function.

${ }^{26}$ Monte Carlo simulations by Judson and Owen (1996) suggest that the bias of the coefficient on right-hand-side variables other than the lagged dependent term may be small for the fixed effects estimator. Since a major part of our interest is in these other coefficients, the FE estimates can therefore still be informative. 
and Bond. Since instrument validity hinges on the absence of serial correlation, a test for secondorder serial correlation developed by Arellano and Bond is also executed.

Fourth, since the degree of labor-market flexibility may influence adjustment costs, the assumption of a common coefficient on the lagged employment term in equation 22 (and its capital based analogue) may be overly restrictive. One way we relax this assumption is to estimate labor-demand equations separately for flexible and rigid labor market states. A second way is by estimating our labor-demand functions using OLS applied to five year differences of the underlying data. By taking differences over a relatively long period, we in effect allow firms to have considerable time to adjust to a given shock to their optimal level of employment. This does away with the need for including a lagged employment term as a regressor and therefore indirectly relaxes the constraint, implicit in equation 22 , that the coefficient on lagged employment is same across states.

Finally, it is important to note that while endogeneity of the right-hand-side variables is always a concern in econometric analysis, the usage of year dummies and reliance on estimators which control for industry-state specific effects (via a within transformation or time differencing) alleviates such concerns. Consider, in particular, the potential endogeneity problem due to the reverse causation from labor to output in the constant-output labor-demand function, as when shocks to technology affect both employment as well as output. Any such shock which is time specific will be captured by our year dummies while shocks which are state specific or industry specific as well as those that are specific to any industry in any particular state will be captured by the industry-state effects (explicitly introduced or implicitly through time differencing). This, in our opinion, would take care of the bulk of the problem associated with the endogeneity of output (and indeed with that of possibly any other right-hand side variable). Of course, it is still possible for there to be some remaining endogeneity between output and employment. Since finding a valid instrument for output is very difficult we carried out the following steps in order to determine how serious a problem the endogeneity of output may be. If we assume constant 
returns to scale then the coefficient of the log of output in the constant-output, "ideal" ("longrun") labor-demand function should be unity. Thus, in this ideal labor-demand function, the log output term can be transferred to the left-hand side with a negative sign and so the dependent variable becomes the demand for labor per unit of output. When we do this, so that the endogeneity of output is not an issue any more, the results are qualitatively extremely similar, thereby telling us that any possible endogeneity not taken care of by controlling for time effects and industry-state effects does not bias our results. ${ }^{27}$

As for the possibility of endogeneity of capital (after controlling for time and industrystate effects), the presence of capital market imperfections in a developing country like India suggests that firms will find it difficult to adjust capital quickly in response to exogenous shocks that may influence employment decisions. Thus the endogeneity of capital is unlikely to be a significant problem in the estimation of the capital-constrained labor-demand function. A more serious econometric problem associated with capital may be that of measurement error. In particular, it is unclear how accurately available measures of capital, which are based on accounting data, capture the true flow of capital services. As described in our discussion on data below (section 4.2) we tackle this problem by adjusting our measure of capital by fuel consumption. Additionally, we take comfort in the fact that the qualitative nature of our results is similar across the three estimators we use: the fixed effects estimator, GMM-IV, and OLS applied to five year differences. Since measurement error in the right-hand-side variables will tend to affect the estimates of these three estimators to different degrees - Griliches and Hausman (1986) note that long difference estimators (such as our five year difference estimator) tend to be less sensitive to measurement error than the fixed effects estimator (which is itself less sensitive to

\footnotetext{
${ }^{27}$ In the context of the fixed effects estimator, constant returns to scale may directly be imposed only in the estimation of the ideal labor-demand function. The estimation of such a function also requires making the additional assumption that adjustment costs are zero (i.e., $\lambda=0$ ). This assumption is not required if we use the long-difference estimator. Our basic results were unaffected using either estimator. We do not present these results in this paper, as constant returns to scale does not seem to be a valid restriction. In particular, allowing returns to scale to be different from one yielded highly significant coefficients of output that are very different from unity (see, for example, Columns 1 and 2 in Tables 3 and 4.)
} 
measurement error than the first difference estimator) - the invariance of our key results across the different estimators suggests to us that measurement error problems may not be particularly serious in our data (See also Westbrook and Tybout (1993)).

\subsection{Data}

The variables required for the estimation of the labor-demand equations, equation (22) and its capital-constrained analogue, are measures of employment, wages, output, capital stocks, factor prices other than wages, and indicators for protection and labor-market rigidity. Our source for production related information and wages is the Annual Survey of Industries (ASI) from 1980 to 1997. ASI data covers establishments registered under the Factory Act and employing ten or more workers (with power and 20 or more workers without power). It provides information on 18 manufacturing industries disaggregated by their location across India's states. Among other things, the ASI reports for each industry-state combination values of gross output produced, intermediate inputs, wage bill, and the book value of capital stocks. It also reports the number of workers. ${ }^{28,29}$ Since the ASI reports monetary values in current prices, appropriate price deflators are needed to convert the nominal values into real ones. We use industry specific wholesale price index (WPI) series to deflate output to constant 1981 rupees. The WPI for machinery, transport equipment and construction is used to deflate the book value of capital stocks. These deflated data are further multiplied by real fuel expenditures to control for capacity utilization as in Harrison (1994). ${ }^{30}$ Dividing the total wage bill by the number of workers is used to arrive at

\footnotetext{
28 The ASI derives its measure of workers by dividing "man days worked" by the number of "working days". Note, however, that our dataset did not contain data on either man days worked or working days for 1997.

29 The term workers refers to production workers (permanent, contract, and temporary). The ASI also reports the number of "total employees", i.e., production and non-production workers. Unfortunately, the ASI uses different definitions for reporting payments to "workers" and "total employees". This prevents us from computing a meaningful wage rate for non-production workers and analyzing labor-demand elasticities for them.

30 We also considered a capital measure without adjustment for capacity utilization. The qualitative results on the effects of trade liberalization and labor-market flexibility were very similar. However, the coefficients on the own wage term tended to be estimated somewhat imprecisely.
} 
wages. $^{31}$ An overall manufacturing sector materials price deflator and materials price deflators which are specific to five broad industry groups are used for measuring the price of material. ${ }^{32}$ The user cost of capital is constructed by multiplying the deflator for capital goods described above by the sum of national money market rates and rate of depreciation (assumed to be $10 \%$ ).

We capture the effects of trade liberalization in two ways. As described in Section 2.1, India embarked on a dramatic program of trade liberalization in 1991. Thus we use a liberalization dummy which takes the value 0 up to 1991 and 1 thereafter to capture the effects of a more liberal trading environment on labor markets. Since this dummy will not capture differences in protection across industries and the effects of year to year changes in protection, we also use industry-year specific tariff rates. ${ }^{33}$ These tariff rates, presented in Table 1 above, are aggregated from tariff rates for 64 industrial product groups, as defined by India's Central Statistical Office, and reported in Pandey (1999) for the years 1988-1997. ${ }^{34}$ In order to arrive at tariff rates for our 18 two-digit industries, we first mapped each of the 64 industrial products groups to one of the 18 industries and then calculated a simple average. We also computed tariff rates for the 18 industries using 1989 import shares as weights. The results of our empirical work

31 An alternative would be to compute wages by dividing the wage bill by man days worked. We do not use this measure of wages in estimating labor-demand equations because (i) man days worked were not available for 1997, the last year of our data; and (ii) the results were insensitive to the measure of wages used in estimation based on all other years.

${ }^{32}$ The five industry groups represent textiles and textiles products, leather and leather products, metals and metal products, chemicals and chemical products, machinery and transport equipment. It was possible to map 12 of our 18 industries into these five groups. For the remaining industries we use the overall manufacturing-wide materials price deflator. All the materials deflators were kindly provided to us by Pushpa Trivedi and their construction is described in Trivedi, Prakash, and Sinate (2000).

${ }^{33}$ While tariff rates on inputs would be a conceptually superior measure to use in the context of the output-constrained labor-demand equation, data availability forces us to use the overall industry tariff instead. This may not be a serious deficiency in our application given the degree of industrial aggregation within each of our 18 industries. Consider the transportation equipment industry, for example. Since this includes the production of both automotive components and finished goods, the average tariff rate for this industry will in part be composed of inputs used in this industry. Thus the average tariff rate for this industry would capture the tariffs on both inputs and outputs for the industry.

${ }^{34}$ Pandey (1999) used published tariff rates and aggregated over all the tariff lines corresponding to the 64 industrial product groups using a simple average. Tariff data was missing in Pandey (1999) for two years: 1989 and 1990. We filled these gaps using linear interpolation. Given the fact that the liberalization program was announced only in mid1991, this procedure is unlikely to entail much error. Indeed, an examination of the tariff rates reported in Pandey (1999) for 1988, 1991, and beyond show very little difference in tariff rates between 1988 and 1991. They drop steadily from 1992 onwards, however. 
were not sensitive to which of the two we used and so we only report the results based on using average tariff rates.

We rely upon inter-state variations in labor laws to account for labor-market rigidity. More specifically we partition states in terms of whether they have flexible labor markets or not. A dummy variable created using this partition may then be interacted with wages (and other factor prices) to determine the impact of labor-market flexibility on labor-demand elasticities. Our procedure to partition states in terms of the flexibility of their labor markets is as follows. We start with Besley and Burgess' (2002) coding of amendments to the Industrial Disputes Act between 1958 and 1992 as pro-employee, anti-employee, or neutral. ${ }^{35}$ Five states are found to have had no amendments in either a pro-employee or anti-employee direction (Assam, Bihar, Haryana, Punjab, and UP). One state, Madhya Pradesh, is found to have had an anti-employee amendment to the IDA in 1982. However, this is negated by a pro-employee amendment in 1983 so that its overall profile with respect to amendments is effectively similar to the five states with no amendment activity. Four states are found to have had (in net year terms) pro-employee amendments (West Bengal, Maharashtra, Gujarat, and Orissa). Finally, five states are found to have had (again in net year terms, as defined in Besley and Burgess, 2002) anti-employee amendments (Andhra Pradesh, Karnataka, Kerala, Rajasthan, and Tamil Nadu). ${ }^{36}$

A natural partition of states would be to treat states with anti-employee amendments to the IDA as those with flexible labor markets. ${ }^{37}$ Such a partition has one puzzling feature,

\footnotetext{
35 Besley and Burgess (2002) consider each state-level amendment to the IDA between 1958 and 1992 and code it as a $1,-1$, or 0 depending on whether the amendment in question is deemed to be pro-employee, anti-employee, or neutral. The scores are then cumulated over time with any multiple amendments for a given year coded to give the general direction of change. See Besley and Burgess (2002) for details. (The Besley and Burgess coding is available at http://econ/lse/ac.uk/staff/rburgess/\#wp.)

${ }^{36}$ With the exception of Karnataka these anti-employee amendments took place in 1980 or earlier. For Karnataka the anti-employee amendments take place in 1988.

${ }^{37}$ An alternative measure of labor-market flexibility/rigidity would have been to use the cumulative scores on amendments. This is the approach of Besley and Burgess (2002). We do not use this approach for the following reasons. First, an important part of our analysis is based on production and protection related data for the years 1988 to 1997. The variation in number of cumulative amendments within states is virtually zero for this period. Since our estimation techniques are based on exploiting variation in the "within" direction, the lack of within state variation in the
} 
however. As noted above Maharashtra and Gujarat, two of India's most industrialized states, have passed pro-employee amendments to the IDA. These states would then be categorized as having inflexible labor markets. However, Indian businesses typically perceive these states to be good locations for setting up manufacturing plants. Conversely, Kerala, a state which has passed anti-employee amendments to the IDA, has an industrial record which is patchy in comparison. Moreover, few Indian businesses would consider it a prime location for setting up manufacturing activity. It is questionable whether Indian businesses would consider Maharashtra and Gujarat to be to be especially good destinations for their capital if their labor markets were very rigid.

A recent research project carried out by the World Bank on the investment climate faced by manufacturing firms across ten Indian states lends strong support to such a switch (see Dollar, Iarossi, and Mengistae (2002) and World Bank (2003)). ${ }^{38}$ First, averages of rankings by managers of surveyed firms led Maharashtra and Gujarat to be the two states categorized as "Best Investment Climate" states while Kerala was one of the three "Poor Investment Climate" states. Indeed, a second finding of the World Bank project seems to suggest that even if IDA amendments have been pro-employee in these two states, their enforcement may have been weak. In particular, the study reports that small and medium sized enterprises receive twice as many factory inspections a year in poor climate states (of which Kerala is a member) as in the two best climate states of Maharashtra and Gujarat. Finally, and perhaps most importantly, a question on firms' perceptions about “over-manning” - i.e., how the optimal level of employment would

cumulative amendments is obviously a problem if we want to introduce cumulative amendments as an independent regressor in our labor-demand equations. Second, in so far as its interaction with factor price terms is concerned, it is not clear to what extent a cardinal measure such as the number of cumulative amendments captures the actual difference in labor-market rigidity across states.

38 Over a thousand firms were surveyed across ten states. Over nine-hundred were manufacturing firms spanning major products of the manufacturing sector (garments, textiles, auto components, drugs and pharmaceuticals, electrical goods, and machine tools). 
differ from current employment given the current level of output - indicated that while overmanning was present in all states, it was lowest on average in Maharashtra and Gujarat. ${ }^{39}$

Thus, we consider a modified partition in which Maharashtra and Gujarat are treated as states with flexible labor markets while Kerala is treated as a state with inflexible labor markets. However, we do point out below how our results change if we were to use the list which emerges if we restrict ourselves to only the Besley and Burgess based measure. ${ }^{40}$ Table 2 provides a list of the states as well as how they are classified according to different criteria.

\section{Empirical analysis}

\subsection{Trade liberalization, labor regulations, and labor-demand elasticities}

As described in Section 3, a more liberal trade policy may be expected to raise the labor-demand elasticity by increasing substitution possibilities among factor inputs and making product demand more elastic. More liberal regulation of labor markets, or weaker enforcement of existing regulations, can have similar effects. Thus less stringent job security laws or poor enforcement of these laws may allow labor to be more easily substituted for other factors. They may also lead to reductions in the adjustment costs associated with labor. We now examine the evidence for these possibilities.

\section{1a Constant-output labor-demand elasticity}

We begin by considering fixed effects (FE) estimates of the constant-output labor-demand function. Although the presence of the lagged dependent variable introduces a bias in the FE

\footnotetext{
39 A supplement to the original World Bank survey carried out in two good investment climate states and one poor investment climate state was aimed at determining the reasons behind over-manning. The results indicated that overmanning was partially the result of labor hoarding in anticipation of higher growth in the future in the good investment climate states but hardly so in the poor investment climate state. In fact, labor regulations were noted as a major reason for over-manning in the latter. This lends indirect support to the notion that given Maharashtra and Gujarat's ranking as best investment climate states, labor regulations have in effect been less binding on firms than the amendments to the IDA may suggest.

40 See footnotes 49 and 52 .
} 
estimates, as pointed out in Section 4.1 above Monte Carlo simulations by Judson and Owen (1996) suggest that the bias of the coefficient on RHS variables other than the lagged dependent term may be small. Since a major part of our interest is in these other coefficients, FE estimates can therefore still be informative.

The first four columns of Table 3 pertain to specifications in which the lagged employment term is omitted while the last four include this. To conserve space, we present estimates of only the parameters of interest. ${ }^{41}$ The results are fairly similar across both types of specifications. The negative and significant estimates of the interaction term involving wages and the post-1991 dummy in Columns 1 and 5 reveal that labor-demand elasticities were significantly higher (in absolute terms) in the years following 1991. Examining the interaction term involving wages and our dummy for flexible labor markets reveals that they were also higher in states with more flexible labor markets. Switching from a dummy indicator for trade liberalization to the more direct, industry specific trade policy based measure in Columns 2 and 6 preserves the result that trade liberalization has made labor demand more elastic: lower tariff rates are associated with a more elastic labor-demand curve. Additionally, labor-demand elasticities continue to be higher in flexible labor markets as in Columns 1 and 5.

To get a sense of the magnitudes involved consider a 110 percentage point decline in average tariffs (average tariff rates in 1988 were around $150 \%$ and fell to around $40 \%$ by 1997). In terms of the estimates of Column 6, this would take the (absolute value of) the long-run labor-

\footnotetext{
41 The variables which are estimated but omitted from the tables include year dummies and all non-wage factor prices and their interactions. Additionally, since all the econometric models we employ exploit variation in the "within" dimension, we cannot include an own term for labor-market flexibility since this only varies by state. We also cannot include own terms for the post-1991 dummy in estimating our labor-demand equations given that we use year dummies. Finally, since the user cost of capital varies only by year, it is not possible to include it and its interaction with the post-1991 dummy.
} 
demand elasticity from 0.11 to 0.20 in a state with inflexible labor markets and from 0.33 to 0.42 in a state with flexible labor markets. ${ }^{42}$

How sensitive are these results to the pooling of data from 18 different industries (such that the parameters of the labor-demand equation are constrained to be equal across these industries)? To address this issue we re-estimate all the specifications described so far by allowing the coefficients of the own factor price and output terms to vary by industry. Our basic results insofar as the effects of trade liberalization and labor-market flexibility on labor elasticity are concerned do not change. Examination of the various interaction terms involving wages in columns $3,4,7$, and 8 reveals that the estimated parameters and the levels of significance are similar to the corresponding estimates based on one set of parameter estimates for all industries. ${ }^{43}$

Though informative, the FE estimates do suffer from the fact that they do not take into account the endogeneity of the lagged employment term. We therefore turn to now to two sets of estimates which deal with this problem in different ways. Table 4 presents the relevant parameters of constant-output labor-demand equation estimated from OLS applied to data differenced by five years. As noted earlier, such long differencing is likely to alleviate biases in the fixed effects estimator since by considering differences over long periods of time, it allows for adjustments to be made in response to shocks to firms' optimal levels of employment. Also, such differencing, as mentioned in subsection 4.1, can reduce the measurement error bias.

On the whole, our results based on long differencing are qualitatively very similar to those obtained from the FE model. Thus, labor-demand elasticity is found to increase in the post 1991 period (Column 1) and with reductions in tariff rates (Column 2). It also increases with

\footnotetext{
${ }^{42}$ Long run elasticities are obtained for Columns $5-8$ by dividing the individual short run elasticities by $1-\lambda$. It may be noted that these estimated elasticities, although on the low side in the case of the states with inflexible labor markets, are well within the range of estimates reported by Hamermesh ((1993); pages 95-96).

43 While the range of estimates for the eighteen industry specific wage terms is rather large (-1.46 to 0.73$)$ and includes some positive values, a majority of the terms are negatively signed in each of the four models (and in fact in all the rest of the models estimated in this paper). The mean, median, and standard deviations of industry specific wage terms for each of the four models are: $-0.09,-0.09,0.42$ (Column 3$) ;-0.30,-0.21,0.52$ (Column 4); $-0.05,-0.07,0.36$ (Column 7); and $-0.27,-0.20,0.49$ (Column 8 ).
} 
flexibility of labor markets (Columns 1 and 2). With the exception of the interaction term involving wages and labor-market flexibility in Column 2 all the relevant interaction terms are statistically significant at conventional levels. Allowing for the coefficients of own factor price terms and output to vary by industry, however, makes even this interaction term significant once again. $^{44}$

In the next two columns, we focus on the tariff based measure of liberalization and estimate the labor-demand function separately for states with inflexible labor regulations (Column 5) and flexible labor regulations (Column 6). ${ }^{45}$ A comparison of parameter estimates across the two samples tells an interesting story. First, states with flexible labor markets have an own wage term which is twice as large in absolute terms as that in states with inflexible labor markets. Second, the interaction term between wages and tariff rates is far larger in states with flexible labor markets. The implications are that a lowering of tariff rates generates a stronger response in labor-demand elasticities in states with flexible labor markets.

Table 5 describes the estimates of key parameters based on the GMM-IV estimator, the second way we deal with the endogeneity of the lagged employment term. The estimates on the lagged employment term are fairly low and in most cases estimated rather imprecisely. The only significant estimate of the lagged employment term is that of Column 1. The implied half life of the adjustment process - i.e. the length of time it takes to move halfway to a new equilibrium in response to a shock - works out to be roughly one-third of a year $(0.30$ years $) .{ }^{46}$ In view of the arguments of critics of India's labor laws, such a value is surprising. At the same time it is possible that adjustment of employment is in fact less costly than the critics claim with the usage of temporary workers and violation of laws diluting their impact.

\footnotetext{
44 The mean, median, and standard deviations of industry specific wage terms are: $-0.10,-0.06,0.40$ (Column 3$)$; and $-0.28,-0.17,0.56$ (Column 4).

45 Results are similar if we use the post-1991 dummy instead. To conserve space we do not report these.

46 The half life ( $\left.\mathrm{t}^{*}\right)$ may be computed as the solution to $\lambda^{t^{*}}=0.5$.
} 
Although a number of the wage terms are not estimated very precisely - the own wage term in Column 1 is insignificant while that in Column 2 is only marginally significant $(15.5 \%$ level), for example - the overall flavor of the results is as before. Thus the interaction terms involving wages and the labor flexibility dummy indicate that labor demand has been more elastic in states with flexible labor markets (Columns 1-4). The results for trade liberalization are also as before, with the relevant parameters estimated fairly precisely. Thus the interaction term involving wages and the post-1991 dummy is negative and significantly so in both Column 1 and Column 3 where the parameters of the labor-demand function are allowed to vary across the 18 industries. Switching to the tariff based measure of trade liberalization, we find that the interaction term between wages and tariff rates is positive as before although it fails to be significant at conventional levels (Column 2). The effect is, however, significant when we allow for industrial heterogeneity in the labor-demand function (Column 4). ${ }^{47}$

As in Table 4, not only do states with flexible labor markets have higher labor-demand elasticities, the elasticities themselves are more responsive to trade liberalization. In states with inflexible labor markets, for example, a reduction in average tariff rates from $150 \%$, the average in 1988 , to $40 \%$, the average in 1997 , is associated with an increase in the long-run elasticity of labor demand from 0.14 to 0.20 . Both estimates fail to be statistically significant, however. ${ }^{48}$ In contrast, the corresponding change in tariffs for states with flexible labor markets is an increase in labor-demand elasticity from 0.23 to 0.52 , with the latter being significant at the $1 \%$ level of significance. $^{49}$

\footnotetext{
47 The mean, median, and standard deviations of industry specific wage terms are: $-0.07,-0.09,0.38$ (Column 3); and $-0.31,-0.30,0.55$ (Column 4).

48 Due to the non-linear nature of the long run elasticities, statistical inference is based on the delta method.

49 The result that labor-demand elasticities are more responsive to reductions in protection in states with more flexible labor markets is sensitive to the classification system we use to categorize states. In particular, if we classify Maharashtra and Gujarat as states with inflexible labor markets and Kerala as one with flexible labor markets - as would be the case if we were to use exactly Besley and Burgess' coding scheme - we get insignificant estimates on the interaction term between wages and tariff rates for both sets of states.
} 


\section{1b Capital-constrained labor-demand elasticity}

We now turn to the capital-constrained labor-demand function to examine the relationship between trade liberalization, labor regulations and labor-demand elasticities. As noted in Section 3, trade liberalization may be expected to affect labor-demand elasticities by increasing substitution possibilities in production and by making product demand more elastic. While the constant-output labor-demand elasticities discussed above are affected only by the former channel, constant-capital elasticities will tend to pick up the effects of both. In addition, examining how the constant-capital labor-demand elasticities behave in response to tariff changes is useful since there may be some concern that we have not used a tariff rate which applies solely to inputs in previous sections. Thus examining the relationship between tariff rate changes and labor-demand elasticities derived from the capital-constrained model provides a useful robustness check on our results so far.

We, here, directly proceed to the discussion of our GMM-IV results (Table 8), as they are fairly similar to our results using the Fixed Effects estimator and OLS applied to five year differences (Tables 6 and 7). In contrast to the results reported in Table 5 for the outputconstrained labor-demand function, the coefficient on lagged employment tends to be precisely estimated across the various models. ${ }^{50}$ In addition, the estimates of the own wage term are significant at the ten percent level or lower in all but one of the models considered. Trade liberalization -whether captured via the post-1991 dummies or in terms of reductions in tariff rates - is found to lead to higher labor-demand elasticities (Columns 1 and 2). This remains the case even when own factor prices and the capital term are allowed to vary by industry (Columns 3 and 4). ${ }^{51}$ Labor-market flexibility also tends to raise labor-demand elasticity, although the effect is not estimated very precisely.

\footnotetext{
${ }^{50}$ However, the implied half-life of the adjustment process is still around $1 / 3^{\text {rd }}$ of a year.

51 It may be noted, however, that allowing for industry level heterogeneity in the labor-demand equation leads to a rejection of the null that second order serial correlation in the differenced errors is absent.
} 
Splitting the overall sample into two sub-samples on the basis of labor-market flexibility confirms the results of Section 5.1a that states with flexible labor markets not only have more elastic labor-demand curves to begin with, the elasticity of demand there also increases with trade liberalization (Column 5 versus Column 6). Thus in terms of the decline in average tariff rates from $150 \%$ in 1988 to $40 \%$ in 1997 , the long-run elasticity of labor demand increased from 0.18 to 0.34 (with the latter being statistically significantly different from zero) in states with inflexible labor markets. The corresponding increase in states with flexible labor markets was 0.28 to 0.52 (with the both point estimates being statistically significantly different from zero). ${ }^{52}$

It is interesting to note that these elasticities are at least as large as those estimated using the output-constrained labor-demand function. Thus while the elasticities here capture the substitution possibilities between labor and materials only, they often more than make up for the omission of substitution possibilities between labor and capital by incorporating the effects of more elastic product demand.

Additionally, the increase in labor-demand elasticity associated with tariff reductions is robust to the simultaneous inclusion of an additional interaction term involving wages and the post-1991 dummy in the case of states with flexible labor markets. Although the estimated model is not shown, the implied long-run elasticity of labor demand is found to increase from 0.28 to 0.52 in response to a tariff reduction from $150 \%$ to $40 \%$. What is important to note is that this increase is driven by the positive and significant estimate on the interaction term involving wages and tariff rates and not the interaction term involving wages and the post 1991 dummy which turns out to be positive but insignificant. This suggests that the increase in elasticity associated with tariff reductions is not being driven by non-trade related phenomena that may have

\footnotetext{
${ }^{52}$ As with the output-constrained labor-demand function, re-classifying Maharashtra and Gujarat as states with inflexible labor markets and Kerala as one with flexible labor markets makes the estimated coefficient on the interaction term involving wages and tariff rates roughly similar (and insignificant) across both types of states. Since a finding of differential effects of trade reforms on labor-demand elasticities across flexible and inflexible labor markets is an intuitively appealing one, we consider the contrasting results as further support of our categorization of Maharashtra and Gujarat as having flexible labor markets and Kerala as having inflexible labor markets.
} 
accompanied trade liberalization and also made labor demand more elastic. In particular, trade liberalization in India has been accompanied by a dramatic deregulation of industrial policy that has curtailed the power of the bureaucracy in the post-1991 period. If the latter is responsible for a more elastic labor demand - for example, because of a weakening of the governments' enforcement of labor regulations - then we would expect the interaction between wages and tariff rates to lose explanatory power in the presence of the interaction between wages and the post1991 dummy. The fact that this does not happen suggests that tariff reductions have been an independent force driving labor-demand elasticities to increase. This result is quite different from Slaughter's (2001) finding for the US.

\subsection{Volatility in wages and employment}

Based on equations (19), (20) and (21) and on our pre- and post-reform estimates of labordemand elasticities $\eta^{D}$, we simulate the values of $d \ln w_{t}^{*} / d \ln A_{t}$ and $d \ln L_{t}^{*} / d \ln A_{t}$ for a range of alternative values of $\eta^{S}$ (Table 9). The first set of labor-demand elasticity estimates (prereform value of 0.26 and the post-reform value of 0.30 ) we use are from our capital-constrained, fixed-effects model without adjustment costs, while the second set of elasticity estimates (prereform value of 0.19 and the post-reform value of 0.35 ) are for the "actual" capital-constrained labor demand estimated using the GMM-IV approach. All the estimates used are for the flexiblelabor states since these would represent an upper bound on the adverse volatility effects of an increase in the labor-demand elasticity. We also discuss the consequences of looking at the implied estimates of the "ideal" labor demand obtained from the second set of elasticity estimates and the estimated value of the parameter $\lambda$ (which is small, implying a short adjustment lag).

We see from Table 9 that when an entire industry in a state takes the wage as given $\left(\eta^{S}=\infty\right)$, changes in productivity (or alternatively output demand conditions) do not lead to changes in the wage, while the percentage change in employment due to a one percent change in 
$A_{t}$ exactly equals the labor-demand elasticity. To the extent that the labor-demand function we estimated turns out to be fairly inelastic, workers are quite insulated from shocks to labor demand. However, employment volatility (and its change) in response to a given productivity volatility (and its change) does increase after the reform by roughly 15\% with the first set of elasticities and by more than $80 \%$ with the second set when the labor supply is assumed to be absolutely flat.

For the polar opposite case of a vertical labor supply curve, there is no effect of a change in $A_{t}$ on employment but the percentage change in wage exactly equals the percentage change in $A_{t}$. However, there is no change in the two derivatives due to the reforms.

With a unitary elastic labor supply curve, the response of wage and employment to a change in $A_{t}$ are the same and under the first set of demand elasticity estimates, a one percent change in $A_{t}$ gives rise to a 0.21 percent change in wage and employment (which means a 0.42 percent change in the wage bill of the industry) prior to the reforms and 0.23 percent change $(0.46$ percent for the wage bill) after the reforms. This, in turn, means that the transmission of volatility increases by less than $10 \%$ for the wage, employment and the wage bill. Under the second set of demand elasticity estimates, this increase in volatility transmission is roughly $62 \%$.

If we assume a much flatter demand $\left(\eta^{S}=10\right)$ which is less than perfectly elastic, these changes are approximately $16 \%$ and $80 \%$ for the two sets of estimated demand elasticities respectively.

We need to point out here that the implied pre-reform and post reform labor-demand elasticities that come out of the second set of estimates (which are "actual" labor-demand elasticities) and an estimate of $\lambda$ between 0.14 and 0.15 are 0.22 and 0.41 respectively, which can lead to a change in volatility transmission of up to 90 percent.

Thus, our elasticity estimates indicate that the transmission of productivity and output demand volatility into the labor market may have gone up significantly following the reforms. 
However, our derivatives also imply that the transmission of productivity growth (in times of sustained growth) also should have gone up significantly, thus implying that the reforms may have moved workers into an environment that can provide them with higher returns but also which is one that is associated with greater risks. The growth aspect is not straight forward to capture and is certainly beyond the scope of this paper and so we will focus only on volatility in empirical results.

We now turn to Table 10 where we present our empirical results on volatility. Here, we compare the volatility of variables in the post-reform period with the their volatility in the prereform period. We break our 18 years of data into three sub-sets: 1980-85, 1986-91 and 199297. ${ }^{53}$ The last period is the post-reform period. For each period, a volatility index for employment, wage rate, total factor productivity (TFP) and output is constructed for each state and industry combination. ${ }^{54}$ We define the index of volatility of a variable as just the residual of the regression of the standard deviation of the logarithm of a variable for a given period on the average growth rate of the variable in the same period, thereby eliminating any growth component. ${ }^{55}$

In Table 10, Vol(.) stands for the volatility of the variable under consideration, work stands for labor, $w$ for wage, $r w$ for real wage and out for output. The additional " $m d$ " at the end of some of the variables represents that the respective variables were calculated by defining labor in terms of man days as opposed to just the number of workers. As in Tables 3-8 "Post 91" is a

\footnotetext{
${ }^{53}$ When wages and employment are defined in terms of man days, the three sub-sets are: 1980-85, 1986-91 and 199196 due to the lack of availability of data on man days for the year 1997.

${ }^{54}$ We calculated the TFP for each state-industry combination for each year by fitting a Cobb-Douglas production function in capital, labor and materials with time, state and industry fixed effects. The TFP then was defined as the residual of this regression plus these fixed effects.

${ }^{55}$ In order to run this regression, we pooled all industries across all states in the ASI (and not just the 15 major states for which we have information on labor-market regulations) over all consecutive six-year sets in our dataset. All regressions in this section have the same state coverage.
} 
dummy variable that takes the value 1 after the year 1991 and is zero otherwise and "tariff" stands for the tariff rate in the third year of each period (six-year sub-set). ${ }^{56}$

In the first panel of Table 10, we focus on the transmission of the volatility of TFP into the labor market with "Post 91 " as the trade-policy variable. In the second panel, the difference is that the "tariff" is the trade-policy variable under consideration. The third and the fourth panels are the analogues of the first two, but with the volatility of TFP being replaced by the output volatility. In all the four panels, the dependent variables (as shown at the top of each column) are the labor market variables (the four measures of wage and two of employment) described above. While the coefficient of the independent volatility variable captures its transmission into the labor-market variable under consideration when the trade policy variable takes the value zero, its interaction with the trade policy variable indicates how this transmission changes with a change in trade policy. Note that trade policy by itself is also introduced as a separate variable.

Looking at the regression results in Table 10, we first see that the volatility of both work and wages, however defined, is positively related to the volatility of TFP and of output throughout. We find that in the pre-reform period the transmission of the volatility of TFP and of output was much higher into employment than into wages, which may suggest a fairly flat labor supply curve. ${ }^{57}$ We find a positive sign on the productivity volatility interacted with post 91 dummy for the nominal wage per worker and the nominal and real wage per worker day. The transmission of volatility into employment did not seem to change after the reform. While these findings are consistent with the theory to the extent that labor-market variables have become more volatile in response to a given TFP volatility, the fact that the transmission into wage volatility increased in the absence of any change in the transmission into employment volatility (especially in the presence of a much higher initial transmission into employment volatility) is

\footnotetext{
${ }^{56}$ When we use tariff in place of post 91, only the last two six year subsets of years are used due to the fact that tariff is available only from 1988 onwards.

57 The transmission of the volatility of output continues to be much higher into employment than into wages even after 1991.
} 
somewhat at odds with the theory. However, overall we find that in both the pre- and post-reform periods, the transmission of TFP volatility into employment was substantially higher than into employment, indicating the existence of a fairly flat labor supply curve.

The results are qualitatively similar when we interact the productivity volatility with tariff instead. The wage and employment volatility are increasing in TFP volatility and negatively related to its interaction with tariff (for the cases for which we have statistical significance), which, given the lower tariff in the post reform period, is the sign consistent with theory. In order to get a sense of the transmission prior to and after the reforms, it should be taken into account that the average tariff in the pre-reform period was roughly $150 \%$ and by the end of the postreform period was roughly $40 \%$, which again shows that the response of employment volatility to TFP volatility was generally higher than that of wage volatility.

We then look at the effect of output volatility as we know employment at any given vector of factor prices is positively related to output and changes in output certainly capture to a large extent changes in product demand as well as TFP. Again, we find that the responsiveness of work volatility to output volatility is generally much stronger than the response of wage volatility. Moreover, the interaction of output volatility with the post 91 dummy is positive and significant only for employment in terms of the number of workers. For all other dependent variables, this interaction term is insignificant. Thus, the third set of regressions is somewhat consistent with the theory and with a fairly elastic labor supply curve.

In the fourth set of regressions, our priors regarding a fairly flat labor supply are vindicated again and this time very strongly so. The output volatility variable is positive and significant in four of the six columns and the ones for employment are significantly higher than for the wages. The interaction between tariff and output volatility has the correct sign and is significant for employment and has the wrong sign and is significant for rw. 
Thus we conclude that the transmission of volatility into the labor market from productivity and output demand did go up following the reforms. Also, this was decreasing in protection across sectors and over time.

\section{Concluding Remarks}

In this paper, we have rigorously looked at how major trade reforms initiated in India in 1991 affected labor-demand elasticities in the manufacturing sector. Our data are disaggregated by state and industry and are for the period 1980-97. Given that we have variation across industries and over time in protection levels and variation across states in labor-market institutions, we believe ours is the first paper that is able to decompose the effect of protection and labor regulations on these elasticities and at the same time look at the interaction between the two.

Our results indicate that labor-demand elasticities increase with reductions in protection. Unlike Slaughter (2001), we do not find time, independent of protection, to dominate our results. Protection thus appears to have the effects that theory would predict. We also find that the response of labor-demand elasticities to protection is conditioned by the nature of labor institutions: states with more flexible labor markets see larger increases in labor-demand elasticities in response to reductions in protection. This is consistent with the point recently made, in the context of growth, by Rodrik, Subramanium, and Trebbi (2002) - that the effect of economic policies (such as trade policy) depends in important ways on the institutional context.

These findings have important implications for public policy and highlight some challenges for policy-making. First, as is theoretically possible given the increases in labordemand elasticities we find that after the reforms, productivity and output volatility have resulted in larger wage and employment volatility.

Second, although our results also suggest that tighter labor regulations- through restrictions on retrenchments and layoffs, for example - can dampen this volatility, it is hard to 
believe that more widespread use of such regulations is the desirable policy response.

Particularly in the context of India's growing integration with the international economy,

allowing Indian firms to be exposed to import competition but constraining their ability to adjust their inputs in response is likely to put domestic firms at a serious disadvantage in terms of their ability to compete. ${ }^{58}$

Finally, the negative consequences of trade on worker welfare uncovered in this paper need to be assessed against its positive effects. Krishna and Mitra (1998) and Hasan (2002), based on analysis of distinct firm level panel data sets from India, find evidence that trade can contribute to productivity. ${ }^{59}$ To the extent that a more elastic labor demand will translate this growth into higher growth in wages and employment, workers have benefited from these reforms. Krishna and Mitra also find a massive reduction in mark-ups across all sectors, thereby implying a significant destruction of monopolies (and the associated dead-weight losses) as well as the transformation of large amounts of producer surpluses into consumer surpluses. Also, the greater ease of substitution between factor inputs that we observe after the reforms probably leads to a more efficient allocation of resources.

In view of the opposing effects that trade can have on workers, what does seem clear is that developing effective institutions that protect the welfare of workers adversely affected by trade without impinging on firms' abilities to adjust to changing conditions is a key challenge for public policy.

\footnotetext{
58 Indeed, this is one of the arguments used by reform-minded policymakers dissatisfied with Indian labor regulations. See in particular the recent report on employment related issues commissioned by the Planning Commission, Government of India (2001).

59 Krishna and Mitra (1998) find that productivity growth increased after trade reforms in many of the manufacturing industries they examine while Hasan (2002) finds that imported technology can be an important source of productivity growth for manufacturing sector firms.
} 


\section{References}

Anant, T.C.A. (2000). "Reforming the labour market," in: Gangopadhyay, S., Wadhwa, W. (Eds.), Economic Reforms for the Poor, Konark, Delhi.

Arellano, Manuel and Bond, Stephen (1991). "Some Tests of Specification for Panel Data: Monte Carlo Evidence and an Application to Employment Equations," Review of Economic Studies 58, 277-97.

Besley, Timothy and Burgess, Robin (2002). "Can Labor Regulation Hinder Economic Performance? Evidence from India," working paper at the London School of Economics.

Dutt, Pushan (2003). "Labor Market Outcomes and Trade Reforms: The Case of India," in Rana Hasan and Devashish Mitra, eds., The Impact of Trade on Labor: Issues, Perspectives, and Experiences from Developing Asia, Elsevier Science B.V.

Dutta, Ramesh (2003). “Labor market, Social Institutions, Economic Reforms and Social Cost”, in Shuji Uchikawa (Ed), Labour Market and Institution in India, 1990s and Beyond, Manohar, New Delhi

Datta Chaudhuri, Mrinal (1996). "Labor markets as social institutions in India," IRIS-India Working Paper No. 10, University of Maryland at College Park.

Dollar, David, Iarossi, Giuseppe, and Mengistae, Taye (2002). "Investment Climate and Economic Performance: Some Firm Level Evidence from India," Working paper at the World Bank.

Feenstra, Robert ed. (2000). The impact of international trade on wages, NBER Conference Report series. Chicago and London: University of Chicago Press.

Feenstra, Robert and Hanson, Gordon (1996). "Globalization, Outsourcing, and Wage Inequality," American Economic Review 86(2), 240-45.

Feenstra, Robert and Hanson, Gordon (1997). "Productivity Measurement and the Impact of Trade and Technology on Wages: Estimates for the U.S., 1972-1990," National Bureau of Economic Research Working Paper: 6052.

Ghose, A. K., (1999). "Current issues in employment policies in India," Economic and Political Weekly 34, 4-10.

Government of India (2001). Report of the Task Force on Employment Opportunities. Planning Commission, Government of India.

Griliches, Zvi and Hausman, Jerry (1986). "Errors in Variables in Panel Data," in Journal of Econometrics, 31, pp. 93-118.

Hamermesh, Daniel (1993). Labor Demand, Princeton, NJ: Princeton University Press.

Harrigan, James (1998). "International Trade and American Wages in General Equilibrium, 1967-1995," National Bureau of Economic Research Working Paper: 6609. 
Harrison, Ann (1994). "Productivity, Imperfect Competition, and Trade Reforms," Journal of International Economics 36, 53-73.

Harrison, Ann and Hanson, Gordon (1999). "Who Gains from Trade Reform? Some Remaining Puzzles," Journal of Development Economics 59(1), 125-54.

Hanson, Gordon H. and Harrison, Ann (1999). "Trade Liberalization and Wage Inequality in Mexico," Industrial and Labor Relations Review 52(2), 271-88.

Hasan, Rana (2002). "The Impact of Imported and Domestic Technologies on the Productivity of Firms: Evidence from Indian Manufacturing Firms," Journal of Development Economics, 69(1), $23-49$.

Haskel, Jonathan and Slaughter, Matthew (2001). "Trade, Technology and U.K. Wage Inequality," Economic Journal 111(468), 163-87.

Hsiao, Cheng (1986). Analysis of Panel Data, Cambridge University Press.

Judson, R.A., Owen, A.L. (1996). "Estimating Dynamic Panel Data Models: A Practical Guide for Macroeconomists," Finance and Economics Discussion Series, Federal Reserve Board, Washington.

Krishna, Pravin and Mitra, Devashish (1998). "Trade Liberalization, Market Discipline and Productivity Growth: New Evidence from India," Journal of Development Economics 56, 447-62.

Krishna, Pravin; Mitra, Devashish and Chinoy, Sajjid (2001). "Trade Liberalization and LaborDemand Elasticities: Evidence from Turkey,” Journal of International Economics 55, 391-409.

Kundu, Amitabh and Gupta, Shalini (1996). "Migration, Urbanisation and Regional Inequality," Economic and Political Weekly, Vol. 33, No. 52, December 28.

Lawrence, Robert Z. and Slaughter, Matthew J. (1993). International Trade and American Wages in the 1980s: Giant Sucking Sound or Small Hiccup? Brookings Papers on Economic Activity (Microeconomics 1993): 161-210.

Levinsohn, James (1993). “Testing the Imports-As-Market-Discipline Hypothesis," Journal of International Economics 35, 1-22.

Maskus, Keith and Bohara, Alok (1985). "The Substitution of Labor, Skills, and Capital in US Manufacturing Trade: Implication for Employment and Incomes," Papers of the Regional Science Association

Nagaraj, R., 2002. Trade and labour market linkages in India: evidence and issues. Economic Series Working Paper 50, East West Center, Hawaii.

Pandey, Mihir (1999). NCAER Report on Trade Protection in India, National Council of Applied Economic Research, New Delhi, India.

Slaughter, Matthew (1999). "Globalisation and Wages: A Tale of Two Perspectives," World Economy 22(5), 609-29. 
Slaughter, Matthew (2001). "International Trade and Labor-Demand Elasticities," Journal of International Economics v54, n1 (June 2001): 27-56.

Ramaswamy, K.V. (2003). "Liberalization, Outsourcing and Industrial Labor Markets in India: Some Preliminary Results", in Shuji Uchikawa (Ed), Labour Market and Institution in India, 1990s and Beyond, Manohar, New Delhi

Revenga, Ana (1992). "Exporting Jobs? The Impact of Import Competition on Employment and Wages in U.S. Manufacturing," Quarterly Journal of Economics 107(1).

Revenga, Ana (1992). "Employment and Wage Effects of Trade Liberalization: The Case of Mexican Manufacturing”, Journal of Labor Economics 15(3).

Rodrik, Dani, Subramanium, Arvind and Trebbi, Francesco (2002). "Institutions Rule: The Primacy of Institutions over Geography and Integration in Economic Development," Working paper at Harvard University.

Rodrik, Dani (1997). Has Globalization Gone Too Far? Washington DC: Institute for International Economics.

Trivedi, Pushpa, Prakash, Anand and Sinate, David (2000). "Productivity in Major Manufacturing Industries in India: 1973-74 to 1997-98," Study Number 20, Department of Economic Analysis and Policy, Reserve Bank of India, Mumbai, India.

Westbrook, D. and J. Tybout (1993). "Estimating Returns to Scale with Large, Imperfect Panels: An Application to Chilean Manufacturing Industries." The World Bank Economic Review, vol. 7, No. 1, pp. 85-112.

World Bank (2003). Improving the Investment Climate in India. The World Bank, Washington DC. 
Table 1. Average tariff rates by industry

\begin{tabular}{lccccc} 
& & & \multicolumn{3}{c}{ Percent Change } \\
& 1988 & 1992 & 1997 & $1988-92$ & $1988-97$ \\
\hline Food & 171.96 & 103.66 & 35.96 & -39.72 & -79.09 \\
Beverages & 150.00 & 138.52 & 59.85 & -7.66 & -60.10 \\
Cotton textiles & 124.55 & 103.64 & 41.14 & -16.79 & -66.97 \\
Wool, etc & 151.99 & 96.45 & 33.84 & -36.54 & -77.74 \\
Jute textiles & 140.00 & 108.75 & 45.00 & -22.32 & -67.86 \\
Textile products & 140.93 & 101.96 & 46.35 & -27.65 & -67.11 \\
Wood & 135.30 & 108.16 & 45.00 & -20.06 & -66.74 \\
Paper & 159.79 & 90.13 & 34.65 & -43.59 & -78.32 \\
Leather & 145.00 & 109.38 & 38.54 & -24.57 & -73.42 \\
Chemicals & 201.56 & 108.20 & 35.32 & -46.32 & -82.48 \\
Rubber & 141.23 & 103.09 & 38.09 & -27.00 & -73.03 \\
Cement, etc & 145.61 & 109.15 & 42.17 & -25.04 & -71.04 \\
Basic metals & 212.17 & 106.32 & 32.49 & -49.89 & -84.69 \\
Metal products & 162.15 & 108.40 & 35.19 & -33.15 & -78.30 \\
Machinery & 139.51 & 107.54 & 29.39 & -22.91 & -78.93 \\
Electrical machinery & 143.17 & 107.84 & 37.34 & -24.68 & -73.92 \\
Transport equipment & 129.96 & 102.46 & 39.27 & -21.16 & -69.78 \\
Other manufacturing & 149.05 & 107.93 & 39.33 & -27.59 & -73.61 \\
\hline Nites Taff
\end{tabular}

Notes. Tariff rates are based on Pandey (1999). 
Table 2. Labor market flexibility across states

\begin{tabular}{|c|c|c|c|}
\hline State & $\begin{array}{l}\text { Besley and Burgess (2002) based } \\
\text { measure }\end{array}$ & $\begin{array}{l}\text { Investment climate } \\
\text { (World Bank, 2003) }\end{array}$ & Composite measure* \\
\hline Andhra Pradesh & Flexible & Good & Flexible \\
\hline Assam & Inflexible & -- & Inflexible \\
\hline Bihar & Inflexible & -- & Inflexible \\
\hline Gujarat & Inflexible & Best & Flexible \\
\hline Haryana & Inflexible & -- & Inflexible \\
\hline Karnataka & Flexible & Good & Flexible \\
\hline Kerala & Flexible & Poor & In-Flexible \\
\hline Madhya Pradesh & Inflexible & -- & Inflexible \\
\hline Maharashtra & Inflexible & Best & Flexible \\
\hline Orissa & Inflexible & -- & Inflexible \\
\hline Punjab & Inflexible & Medium & Inflexible \\
\hline Rajasthan & Flexible & -- & Flexible \\
\hline Tamil Nadu & Flexible & Good & Flexible \\
\hline Uttar Pradesh & Inflexible & Poor & Inflexible \\
\hline West Bengal & Inflexible & Poor & Inflexible \\
\hline
\end{tabular}

Notes. (*) Composite measure is derived by reassigning Gujarat and Maharashtra as states with flexible labor markets and Kerala as a state with inflexible labor markets on the basis of World Bank (2003). 
Table 3. Output constrained labor demand (With industry-state fixed effects)

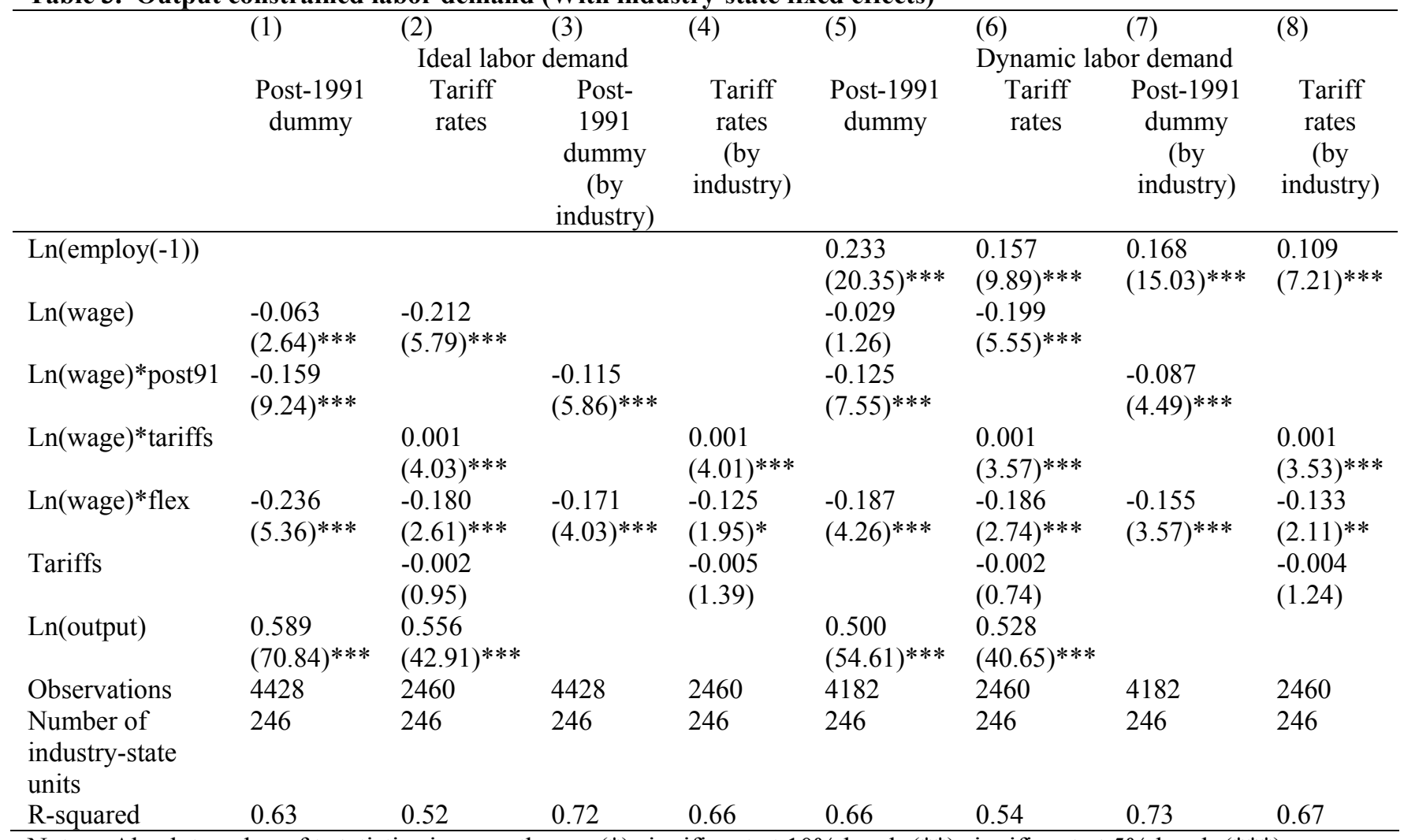

Notes. Absolute value of $t$ statistics in parentheses. $(*)$ significant at $10 \%$ level; (**) significant at 5\% level; (***) significant at $1 \%$ level. Variables included in estimation but not reported: non-wage factor prices (and their interactions with trade policy and flexibility variables) and year dummies. 
Table 4. Output constrained labor demand (Five year differences)

\begin{tabular}{|c|c|c|c|c|c|c|}
\hline & $\begin{array}{l}\text { (1) } \\
\text { Post-1991 } \\
\text { dummy }\end{array}$ & $\begin{array}{l}\text { (2) } \\
\text { Tariff rates }\end{array}$ & $\begin{array}{l}\text { (3) } \\
\text { Post-1991 } \\
\text { dummy } \\
\text { (by } \\
\text { industry) }\end{array}$ & $\begin{array}{l}\text { (4) } \\
\text { Tariff rates } \\
\text { (by } \\
\text { industry) }\end{array}$ & $\begin{array}{l}(5) \\
\text { Inflexible } \\
\text { sample }\end{array}$ & $\begin{array}{l}\text { (6) } \\
\text { Flexible } \\
\text { sample }\end{array}$ \\
\hline Ln(wage) & $\begin{array}{l}-0.057 \\
(2.05)^{* *}\end{array}$ & $\begin{array}{l}-0.226 \\
(4.65)^{* * *}\end{array}$ & & & $\begin{array}{l}-0.206 \\
(3.60) * * *\end{array}$ & $\begin{array}{l}-0.416 \\
(5.01)^{* * *}\end{array}$ \\
\hline Ln(wage)*post91 & $\begin{array}{l}-0.136 \\
(6.57)^{* * *}\end{array}$ & & $\begin{array}{l}-0.084 \\
(3.87)^{* * *}\end{array}$ & & & \\
\hline Ln(wage) $*$ tariffs & & $\begin{array}{l}0.001 \\
(3.32)^{* * *}\end{array}$ & & $\begin{array}{l}0.001 \\
(2.85)^{* * *}\end{array}$ & $\begin{array}{l}0.000 \mathrm{~A} \\
(1.12)\end{array}$ & $\begin{array}{l}0.002 \\
(4.50) * * *\end{array}$ \\
\hline Ln(wage)*flex & $\begin{array}{l}-0.236 \\
(4.67)^{* * *}\end{array}$ & $\begin{array}{l}-0.130 \\
(1.35)\end{array}$ & $\begin{array}{l}-0.187 \\
(3.87)^{* * *}\end{array}$ & $\begin{array}{l}-0.186 \\
(2.11)^{* *}\end{array}$ & & \\
\hline Tariffs & & $\begin{array}{l}-0.005 \\
(1.29)\end{array}$ & & $\begin{array}{l}-0.012 \\
(2.00)^{* *}\end{array}$ & $\begin{array}{l}-0.003 \\
(0.49)\end{array}$ & $\begin{array}{l}-0.007 \\
(1.67)^{*}\end{array}$ \\
\hline Ln(output) & $\begin{array}{l}0.561 \\
(56.08) * * *\end{array}$ & $\begin{array}{l}0.561 \\
(31.33)^{* * *}\end{array}$ & & & $\begin{array}{l}0.587 \\
(24.91) * * *\end{array}$ & $\begin{array}{l}0.499 \\
(18.11)^{* * *}\end{array}$ \\
\hline Observations & 3198 & 1230 & 3198 & 1230 & 715 & 515 \\
\hline R-squared & 0.56 & 0.52 & 0.67 & 0.68 & 0.52 & 0.55 \\
\hline
\end{tabular}


Table 5. Output constrained labor demand (GMM-IV)

\begin{tabular}{|c|c|c|c|c|c|c|}
\hline & $\begin{array}{l}\text { (1) } \\
\text { Post-1991 } \\
\text { dummy }\end{array}$ & $\begin{array}{l}\text { (2) } \\
\text { Tariff rates }\end{array}$ & $\begin{array}{l}\text { (3) } \\
\text { Post-1991 } \\
\text { dummy } \\
\text { (by } \\
\text { industry) }\end{array}$ & $\begin{array}{l}\text { (4) } \\
\text { Tariff rates } \\
\text { (by } \\
\text { industry) }\end{array}$ & $\begin{array}{l}(5) \\
\text { Inflexible } \\
\text { sample }\end{array}$ & $\begin{array}{l}(6) \\
\text { Flexible } \\
\text { sample }\end{array}$ \\
\hline Ln(employ(-1)) & $\begin{array}{l}0.101 \\
(2.03)^{* *}\end{array}$ & $\begin{array}{l}0.088 \\
(1.04)\end{array}$ & $\begin{array}{l}0.022 \\
(0.62)\end{array}$ & $\begin{array}{l}0.066 \\
(1.32)\end{array}$ & $\begin{array}{l}0.088 \\
(0.97)\end{array}$ & $\begin{array}{l}0.130 \\
(1.29)\end{array}$ \\
\hline Ln(wage) & $\begin{array}{l}-0.062 \\
(0.57)\end{array}$ & $\begin{array}{l}-0.237 \\
(1.42)\end{array}$ & & & $\begin{array}{l}-0.209 \\
(1.15)\end{array}$ & $\begin{array}{l}-0.539 \\
(3.45)^{* * *}\end{array}$ \\
\hline Ln(wage)*post91 & $\begin{array}{l}-0.161 \\
(2.59)^{* * *}\end{array}$ & & $\begin{array}{l}-0.150 \\
(2.67)^{* * *}\end{array}$ & & & \\
\hline Ln(wage)*tariffs & & $\begin{array}{l}0.001 \\
(1.35)\end{array}$ & & $\begin{array}{l}0.001 \\
(1.97)^{* *}\end{array}$ & $\begin{array}{l}0.001 \\
(0.50)\end{array}$ & $\begin{array}{l}0.002 \\
(3.81)^{* * *}\end{array}$ \\
\hline Ln(wage)*flex & $\begin{array}{l}-0.226 \\
(1.44)\end{array}$ & $\begin{array}{l}-0.302 \\
(1.60)\end{array}$ & $\begin{array}{l}-0.117 \\
(0.98)\end{array}$ & $\begin{array}{l}-0.195 \\
(1.42)\end{array}$ & & \\
\hline Tariffs & & $\begin{array}{l}0.001 \\
(0.32)\end{array}$ & & $\begin{array}{l}-0.006 \\
(1.82)^{*}\end{array}$ & $\begin{array}{l}0.001 \\
(0.13)\end{array}$ & $\begin{array}{l}-0.001 \\
(0.45)\end{array}$ \\
\hline Ln(output) & $\begin{array}{l}0.617 \\
(13.36) * * *\end{array}$ & $\begin{array}{l}0.577 \\
(9.59)^{* * *}\end{array}$ & & & $\begin{array}{l}0.624 \\
(8.62)^{* * *}\end{array}$ & $\begin{array}{l}0.425 \\
(5.82)^{* * *}\end{array}$ \\
\hline Observations & 3936 & 2214 & 3936 & 2214 & 1287 & 927 \\
\hline $\begin{array}{l}\text { Number of industry-state } \\
\text { units }\end{array}$ & 246 & 246 & 246 & 246 & 143 & 103 \\
\hline $\mathrm{s}-\operatorname{corr} 2^{\#}$ & 0.87 & 0.13 & -0.77 & -0.69 & 0.48 & -1.24 \\
\hline
\end{tabular}

Notes. Absolute value of robust z statistics in parentheses. (*) significant at $10 \%$ level; (**) significant at 5\% level; $(* * *)$ significant at $1 \%$ level. $\left(^{\#}\right)$ Test statistic for second order serial correlation. Variables included in estimation in terms of first differences but not reported: non-wage factor prices (and their interactions with trade policy and flexibility variables) and year dummies. 
Table 6. Capital constrained labor demand (With industry-state fixed effects)

\begin{tabular}{|c|c|c|c|c|c|c|c|c|}
\hline & (1) & $(2)$ & (3) & (4) & (5) & $(6)$ & (7) & (8) \\
\hline & \multicolumn{4}{|c|}{ Ideal labor demand } & \multicolumn{4}{|c|}{ Dynamic labor demand } \\
\hline & $\begin{array}{c}\text { Post-1991 } \\
\text { dummy }\end{array}$ & $\begin{array}{l}\text { Tariff } \\
\text { rates }\end{array}$ & $\begin{array}{c}\text { Post- } \\
1991 \\
\text { dummy } \\
\text { (by } \\
\text { industry) }\end{array}$ & $\begin{array}{c}\text { Tariff } \\
\text { rates } \\
\text { (by } \\
\text { industry) }\end{array}$ & $\begin{array}{l}\text { Post-1991 } \\
\text { dummy }\end{array}$ & $\begin{array}{l}\text { Tariff } \\
\text { rates }\end{array}$ & $\begin{array}{c}\text { Post-1991 } \\
\text { dummy } \\
\text { (by } \\
\text { industry) }\end{array}$ & $\begin{array}{c}\text { Tariff } \\
\text { rates } \\
\text { (by } \\
\text { industry) }\end{array}$ \\
\hline $\operatorname{Ln}($ employ $(-1))$ & & & & & $\begin{array}{c}0.294 \\
(26.13)^{* * *}\end{array}$ & $\begin{array}{c}0.216 \\
(13.94)^{* * *}\end{array}$ & $\begin{array}{c}0.239 \\
(21.26)^{* * *}\end{array}$ & $\begin{array}{c}0.184 \\
(12.24)^{* * *}\end{array}$ \\
\hline Ln(wage) & $\begin{array}{c}-0.118 \\
(4.71)^{* * *}\end{array}$ & $\begin{array}{c}-0.116 \\
(3.17)^{* * *}\end{array}$ & & & $\begin{array}{c}-0.093 \\
(3.90)^{* * *}\end{array}$ & $\begin{array}{c}-0.114 \\
(3.23)^{* * *}\end{array}$ & & \\
\hline Ln(wage)*post91 & $\begin{array}{c}-0.041 \\
(2.28)^{* *}\end{array}$ & & $\begin{array}{c}-0.103 \\
(5.03)^{* * *}\end{array}$ & & $\begin{array}{c}-0.018 \\
(1.06)\end{array}$ & & $\begin{array}{c}-0.060 \\
(3.06)^{* * *}\end{array}$ & \\
\hline Ln(wage)*tariffs & & $\begin{array}{c}0.000 \mathrm{~A} \\
(0.23)\end{array}$ & & $\begin{array}{c}0.001 \\
(2.57)^{* *}\end{array}$ & & $\begin{array}{c}-0.000 \mathrm{~A} \\
(0.37)\end{array}$ & & $\begin{array}{l}0.000 \mathrm{~A} \\
(1.74)^{*}\end{array}$ \\
\hline Ln(wage)*flex & $\begin{array}{c}-0.144 \\
(3.13)^{* * *}\end{array}$ & $\begin{array}{c}-0.199 \\
(2.84)^{* * *}\end{array}$ & $\begin{array}{c}-0.131 \\
(2.94)^{* * *}\end{array}$ & $\begin{array}{c}-0.169 \\
(2.54)^{* *}\end{array}$ & $\begin{array}{c}-0.125 \\
(2.81)^{* * *}\end{array}$ & $\begin{array}{c}-0.202 \\
(3.00)^{* * *}\end{array}$ & $\begin{array}{c}-0.102 \\
(2.30)^{* *}\end{array}$ & $\begin{array}{c}-0.168 \\
(2.61)^{* * *}\end{array}$ \\
\hline Tariffs & & $\begin{array}{l}0.001 \\
(0.75)\end{array}$ & & $\begin{array}{l}0.001 \\
(0.73)\end{array}$ & & $\begin{array}{l}0.002 \\
(1.21)\end{array}$ & & $\begin{array}{l}0.002 \\
(1.13)\end{array}$ \\
\hline Ln(capital) & $\begin{array}{c}0.263 \\
(64.68)^{* * *}\end{array}$ & $\begin{array}{c}0.246 \\
(41.56)^{* * *}\end{array}$ & & & $\begin{array}{c}0.219 \\
(52.46)^{* * *}\end{array}$ & $\begin{array}{c}0.236 \\
(41.24)^{* * *}\end{array}$ & & \\
\hline Observations & 4428 & 2460 & 4428 & 2460 & 4182 & 2460 & 4182 & 2460 \\
\hline $\begin{array}{l}\text { Number of } \\
\text { industry-state } \\
\text { units }\end{array}$ & 246 & 246 & 246 & 246 & 246 & 246 & 246 & 246 \\
\hline R-squared & 0.59 & 0.51 & 0.68 & 0.63 & 0.64 & 0.55 & 0.71 & 0.65 \\
\hline
\end{tabular}

Notes. Absolute value of $t$ statistics in parentheses. $(*)$ significant at $10 \%$ level; (**) significant at 5\% level; (***) significant at $1 \%$ level. Variables included in estimation but not reported: material prices (and its interactions with trade policy and flexibility variables) and year dummies. (A) Estimate is zero to the third decimal place. 
Table 7. Capital constrained labor demand (Five year differences)

\begin{tabular}{|c|c|c|c|c|c|c|}
\hline & $\begin{array}{l}\text { (1) } \\
\text { Post-1991 } \\
\text { dummy }\end{array}$ & $\begin{array}{l}\text { (2) } \\
\text { Tariff } \\
\text { rates }\end{array}$ & $\begin{array}{l}\text { (3) } \\
\text { Post-1991 } \\
\text { dummy } \\
\text { (by } \\
\text { industry) }\end{array}$ & $\begin{array}{l}\text { (4) } \\
\text { Tariff } \\
\text { rates } \\
\text { (by } \\
\text { industry) }\end{array}$ & $\begin{array}{l}(5) \\
\text { Inflexible } \\
\text { sample }\end{array}$ & $\begin{array}{l}(6) \\
\text { Flexible } \\
\text { sample }\end{array}$ \\
\hline Ln(wage) & $\begin{array}{l}-0.072 \\
(2.44)^{* *}\end{array}$ & $\begin{array}{l}-0.126 \\
(2.57)^{* *}\end{array}$ & & & $\begin{array}{l}-0.102 \\
(1.78)^{*}\end{array}$ & $\begin{array}{l}-0.312 \\
(3.60) * * *\end{array}$ \\
\hline Ln(wage)*post91 & $\begin{array}{l}-0.050 \\
(2.33)^{* *}\end{array}$ & & $\begin{array}{l}-0.064 \\
(2.77)^{* * *}\end{array}$ & & & \\
\hline Ln(wage)*tariffs & & $\begin{array}{l}-0.000 \mathrm{~A} \\
(0.08)\end{array}$ & & $\begin{array}{l}0.000 \mathrm{~A} \\
(1.25)\end{array}$ & $\begin{array}{l}-0.000 \mathrm{~A} \\
(1.27)\end{array}$ & $\begin{array}{l}0.001 \\
(2.23)^{* *}\end{array}$ \\
\hline Ln(wage)*flex & $\begin{array}{l}-0.183 \\
(3.48)^{* * *}\end{array}$ & $\begin{array}{l}-0.113 \\
(1.16)\end{array}$ & $\begin{array}{l}-0.155 \\
(3.02)^{* * *}\end{array}$ & $\begin{array}{l}-0.133 \\
(1.45)\end{array}$ & & \\
\hline Tariffs & & $\begin{array}{l}0.001 \\
(0.45)\end{array}$ & & $\begin{array}{l}0.002 \\
(0.77)\end{array}$ & $\begin{array}{l}0.000 \mathrm{~A} \\
(0.10)\end{array}$ & $\begin{array}{l}0.001 \\
(0.49)\end{array}$ \\
\hline Ln(capital) & $\begin{array}{l}0.239 \\
(50.92)^{* * *}\end{array}$ & $\begin{array}{l}0.241 \\
(29.54)^{* * *}\end{array}$ & & & $\begin{array}{l}0.253 \\
(24.06)^{* * *}\end{array}$ & $\begin{array}{l}0.214 \\
(15.82)^{* * *}\end{array}$ \\
\hline Observations & 3198 & 1230 & 3198 & 1230 & 715 & 515 \\
\hline R-squared & 0.52 & 0.50 & 0.61 & 0.64 & 0.50 & 0.50 \\
\hline
\end{tabular}

Notes. Absolute value of $t$ statistics in parentheses. $(*)$ significant at $10 \%$ level; $(* *)$ significant at 5\% level; (***) significant at $1 \%$ level. Variables included in estimation in terms of five year differences but not reported: material prices (and its interactions with trade policy and flexibility variables) and year dummies. (A) Estimate is zero to the third decimal place. 
Table 8. Capital constrained labor demand (GMM-IV)

\begin{tabular}{|c|c|c|c|c|c|c|}
\hline & $\begin{array}{l}\text { (1) } \\
\text { Post-1991 } \\
\text { dummy }\end{array}$ & $\begin{array}{l}\text { (2) } \\
\text { Tariff rates }\end{array}$ & $\begin{array}{l}\text { (3) } \\
\text { Post-1991 } \\
\text { dummy } \\
\text { (by } \\
\text { industry) }\end{array}$ & $\begin{array}{l}\text { (4) } \\
\text { Tariff rates } \\
\text { (by } \\
\text { industry) }\end{array}$ & $\begin{array}{l}(5) \\
\text { Inflexible } \\
\text { sample }\end{array}$ & $\begin{array}{l}\text { (6) } \\
\text { Flexible } \\
\text { sample }\end{array}$ \\
\hline Ln(employ(-1)) & $\begin{array}{l}0.144 \\
(2.99) * * *\end{array}$ & $\begin{array}{l}0.144 \\
(1.94)^{*}\end{array}$ & $\begin{array}{l}0.079 \\
(2.14)^{* * *}\end{array}$ & $\begin{array}{l}0.144 \\
(3.12)^{* * *}\end{array}$ & $\begin{array}{l}0.150 \\
(1.93)^{*}\end{array}$ & $\begin{array}{l}0.135 \\
(1.30)\end{array}$ \\
\hline Ln(wage) & $\begin{array}{l}-0.101 \\
(1.01)\end{array}$ & $\begin{array}{l}-0.324 \\
(2.24)^{* *}\end{array}$ & & & $\begin{array}{l}-0.338 \\
(2.30)^{* *}\end{array}$ & $\begin{array}{l}-0.520 \\
(3.83)^{* * *}\end{array}$ \\
\hline Ln(wage)*post91 & $\begin{array}{l}-0.164 \\
(3.38)^{* * *}\end{array}$ & & $\begin{array}{l}-0.161 \\
(3.05)^{* * *}\end{array}$ & & & \\
\hline Ln(wage)*tariffs & & $\begin{array}{l}0.001 \\
(2.16)^{* *}\end{array}$ & & $\begin{array}{l}0.001 \\
(2.30)^{* *}\end{array}$ & $\begin{array}{l}0.001 \\
(1.41)\end{array}$ & $\begin{array}{l}0.002 \\
(3.44)^{* * *}\end{array}$ \\
\hline Ln(wage)*flex & $\begin{array}{l}-0.190 \\
(1.43)\end{array}$ & $\begin{array}{l}-0.284 \\
(1.58)\end{array}$ & $\begin{array}{l}-0.151 \\
(1.40)\end{array}$ & $\begin{array}{l}-0.238 \\
(1.83)^{*}\end{array}$ & & \\
\hline Tariffs & & $\begin{array}{l}0.001 \\
(0.55)\end{array}$ & & $\begin{array}{l}-0.002 \\
(0.59)\end{array}$ & $\begin{array}{l}-0.001 \\
(0.27)\end{array}$ & $\begin{array}{l}0.002 \\
(0.87)\end{array}$ \\
\hline Ln(capital) & $\begin{array}{l}0.279 \\
(12.96)^{* * *}\end{array}$ & $\begin{array}{l}0.272 \\
(9.42)^{* * *}\end{array}$ & & & $\begin{array}{l}0.292 \\
(8.61)^{* * *}\end{array}$ & $\begin{array}{l}0.197 \\
(7.30)^{* * *}\end{array}$ \\
\hline Observations & 3936 & 2214 & 3936 & 2214 & 1287 & 927 \\
\hline $\begin{array}{l}\text { Number of industry-state } \\
\text { units }\end{array}$ & 246 & 246 & 246 & 246 & 143 & 103 \\
\hline $\mathrm{s}-\operatorname{corr} 2^{\#}$ & 1.89 & 0.23 & 0.68 & -1.68 & 0.35 & -0.29 \\
\hline
\end{tabular}

Notes. Absolute value of robust z statistics in parentheses. $(*)$ significant at $10 \%$ level; $(* *)$ significant at $5 \%$ level; $(* * *)$ significant at $1 \%$ level. $\left(^{\#}\right)$ Test statistic for second order serial correlation. Variables included in estimation in terms of first differences but not reported: material prices (and its interactions with trade policy and flexibility variables) and year dummies. 
Table 9: Simulated variation in equilibrium wages and employment in response to estimated changes in labor-demand elasticity

$$
\eta^{S} \quad \eta^{S}
$$

\begin{tabular}{|c|c|c|c|c|c|c|c|c|c|c|}
\hline & & $\infty$ & 10 & 1 & 0 & & $\infty$ & 10 & 1 & 0 \\
\hline \multirow{3}{*}{$\frac{d \ln w_{t}^{*}}{d \ln A_{t}}$} & Pre-reform & 0 & 0.025 & 0.21 & 1 & Pre-reform & 0 & 0.019 & 0.16 & 1 \\
\hline & $\eta^{D}=0.26$ & & & & & $\eta^{D}=0.19$ & & & & \\
\hline & $\begin{array}{l}\text { Post-reform } \\
\eta^{D}=0.30\end{array}$ & 0 & 0.029 & 0.23 & 1 & $\begin{array}{l}\text { Post-reform } \\
\eta^{D}=0.35\end{array}$ & 0 & 0.034 & 0.26 & 1 \\
\hline \multirow{4}{*}{$\frac{d \ln L_{t}^{*}}{d \ln A_{t}}$} & Pre-reform & 0.26 & 0.25 & 0.21 & 0 & Pre-reform & 0.19 & 0.19 & 0.16 & 0 \\
\hline & $\eta^{D}=0.26$ & & & & & $\eta^{D}=0.19$ & & & & \\
\hline & Post-reform & 0.30 & 0.29 & 0.23 & 0 & Post-reform & 0.35 & 0.34 & 0.26 & 0 \\
\hline & $\eta^{D}=0.30$ & & & & & $\eta^{D}=0.35$ & & & & \\
\hline
\end{tabular}


Table 10: Employment and wage volatility in response to TFP and output volatility (with state and industry fixed effects)

\begin{tabular}{|c|c|c|c|c|c|c|}
\hline & $\begin{array}{l}\text { (1) } \\
\text { Vol(work }\end{array}$ & $\begin{array}{l}\text { (2) } \\
\text { Vol(w) }\end{array}$ & $\begin{array}{l}(3) \\
\text { Vol(rw) }\end{array}$ & $\begin{array}{l}\text { (4) } \\
\text { Vol(workmd) }\end{array}$ & $\begin{array}{l}\text { (5) } \\
\text { Vol(wmd) }\end{array}$ & $\begin{array}{l}\text { (6) } \\
\text { Vol(rwmd) }\end{array}$ \\
\hline post91 & $\begin{array}{l}0.018 \\
(1.41)\end{array}$ & $\begin{array}{l}-0.006 \\
(1.01)\end{array}$ & $\begin{array}{l}-0.009 \\
(1.25)\end{array}$ & $\begin{array}{l}0.002 \\
(0.19)\end{array}$ & $\begin{array}{l}-0.005 \\
(0.87)\end{array}$ & $\begin{array}{l}-0.003 \\
(0.37)\end{array}$ \\
\hline Vol(TFP) & $\begin{array}{l}0.828 \\
(7.81)^{* * *}\end{array}$ & $\begin{array}{l}0.089 \\
(1.65)^{*}\end{array}$ & $\begin{array}{l}0.294 \\
(4.76)^{* * *}\end{array}$ & & & \\
\hline Vol(TFPmd) & & & & $\begin{array}{l}0.757 \\
(7.79) * * *\end{array}$ & $\begin{array}{l}0.089 \\
(1.70)^{*}\end{array}$ & $\begin{array}{l}0.327 \\
(5.46)^{* * *}\end{array}$ \\
\hline Vol(TFP)*post91 & $\begin{array}{l}-0.033 \\
(0.16)\end{array}$ & $\begin{array}{l}0.298 \\
(2.92)^{* * *}\end{array}$ & $\begin{array}{l}0.187 \\
(1.60)\end{array}$ & & & \\
\hline Vol(TFPmd)*post9 & & & & $\begin{array}{l}0.195 \\
(1.12)\end{array}$ & $\begin{array}{l}0.375 \\
(4.00)^{* * *}\end{array}$ & $\begin{array}{l}0.520 \\
(4.87)^{* * *}\end{array}$ \\
\hline Observations & 809 & 809 & 809 & 808 & 808 & 808 \\
\hline R-squared & 0.32 & 0.18 & 0.25 & 0.37 & 0.17 & 0.28 \\
\hline & $\begin{array}{l}\text { (1) } \\
\text { Vol(work) }\end{array}$ & $\begin{array}{l}\text { (2) } \\
\text { Vol(w) }\end{array}$ & $\begin{array}{l}\text { (3) } \\
\text { Vol(rw) }\end{array}$ & $\begin{array}{l}\text { (4) } \\
\text { Vol(workmd) }\end{array}$ & $\begin{array}{l}\text { (5) } \\
\text { Vol(wmd) }\end{array}$ & $\begin{array}{l}\text { (6) } \\
\text { Vol(rwmd) }\end{array}$ \\
\hline tariff & $\begin{array}{l}-0.000 \mathrm{~A} \\
(0.32)\end{array}$ & $\begin{array}{l}-0.000 \mathrm{~A} \\
(0.15)\end{array}$ & $\begin{array}{l}-0.000 \mathrm{~A} \\
(0.79)\end{array}$ & $\begin{array}{l}0.000 \mathrm{~A} \\
(0.05)\end{array}$ & $\begin{array}{l}-0.000 \mathrm{~A} \\
(0.05)\end{array}$ & $\begin{array}{l}-0.000 \mathrm{~A} \\
(1.08)\end{array}$ \\
\hline Vol(TFP) & $\begin{array}{l}0.661 \\
(1.85)^{*}\end{array}$ & $\begin{array}{l}0.434 \\
(2.80)^{* * *}\end{array}$ & $\begin{array}{l}0.427 \\
(2.46)^{* *}\end{array}$ & & & \\
\hline Vol(TFPmd) & & & & $\begin{array}{l}1.126 \\
(2.80)^{* * *}\end{array}$ & $\begin{array}{l}0.859 \\
(4.46)^{* * *}\end{array}$ & $\begin{array}{l}1.201 \\
(5.54)^{* * *}\end{array}$ \\
\hline Vol(TFP)*tariff & $\begin{array}{l}0.002 \\
(0.70)\end{array}$ & $\begin{array}{l}-0.001 \\
(0.72)\end{array}$ & $\begin{array}{l}0.001 \\
(0.49)\end{array}$ & & & \\
\hline Vol(TFPmd)*tariff & & & & $\begin{array}{l}0.000 \mathrm{~A} \\
(0.04)\end{array}$ & $\begin{array}{l}-0.004 \\
(2.29)^{* *}\end{array}$ & $\begin{array}{l}-0.004 \\
(2.33)^{* *}\end{array}$ \\
\hline Observations & 545 & 545 & 545 & 544 & 544 & 544 \\
\hline R-squared & 0.30 & 0.22 & 0.32 & 0.38 & 0.23 & 0.38 \\
\hline & $\begin{array}{l}\text { (1) } \\
\text { Vol(work) }\end{array}$ & $\begin{array}{l}(2) \\
\text { Vol(w) }\end{array}$ & $\begin{array}{l}\text { (3) } \\
\text { Vol(rw) }\end{array}$ & $\begin{array}{l}\text { (4) } \\
\text { Vol(workmd) }\end{array}$ & $\begin{array}{l}\text { (5) } \\
\text { Vol(wmd) }\end{array}$ & $\begin{array}{l}\text { (6) } \\
\text { Vol(rwmd) }\end{array}$ \\
\hline post91 & $\begin{array}{l}0.015 \\
(1.56)\end{array}$ & $\begin{array}{l}-0.006 \\
(1.03)\end{array}$ & $\begin{array}{l}-0.010 \\
(1.44)\end{array}$ & $\begin{array}{l}-0.002 \\
(0.27)\end{array}$ & $\begin{array}{l}-0.006 \\
(0.97)\end{array}$ & $\begin{array}{l}-0.004 \\
(0.63)\end{array}$ \\
\hline Vol(out) & $\begin{array}{l}0.583 \\
(20.40)^{* * *}\end{array}$ & $\begin{array}{l}0.148 \\
(8.06)^{* * *}\end{array}$ & $\begin{array}{l}0.212 \\
(10.19)^{* * *}\end{array}$ & $\begin{array}{l}0.611 \\
(23.35)^{* * *}\end{array}$ & $\begin{array}{l}0.101 \\
(5.40)^{* * *}\end{array}$ & $\begin{array}{l}0.162 \\
(7.50)^{* * *}\end{array}$ \\
\hline Vol(out)*post91 & $\begin{array}{l}0.094 \\
(2.16)^{* * *}\end{array}$ & $\begin{array}{l}-0.015 \\
(0.53)\end{array}$ & $\begin{array}{l}-0.044 \\
(1.38)\end{array}$ & $\begin{array}{l}-0.038 \\
(0.92)\end{array}$ & $\begin{array}{l}-0.013 \\
(0.45)\end{array}$ & $\begin{array}{l}-0.040 \\
(1.18)\end{array}$ \\
\hline $\begin{array}{l}\text { Observations } \\
\text { R-squared }\end{array}$ & $\begin{array}{l}809 \\
0.61\end{array}$ & $\begin{array}{l}809 \\
0.25\end{array}$ & $\begin{array}{l}809 \\
0.33\end{array}$ & $\begin{array}{l}808 \\
0.64\end{array}$ & $\begin{array}{l}808 \\
0.18\end{array}$ & $\begin{array}{l}808 \\
0.26\end{array}$ \\
\hline & $\begin{array}{l}\text { 1) } \\
\text { ol(work) }\end{array}$ & $\begin{array}{l}(2) \\
\text { Vol(w) }\end{array}$ & $\begin{array}{l}\text { (3) } \\
\text { Vol(rw) }\end{array}$ & $\begin{array}{l}\text { (4) } \\
\text { Vol(workmd) }\end{array}$ & $\begin{array}{l}\text { (5) } \\
\text { Vol(wmd) }\end{array}$ & $\begin{array}{l}\text { (6) } \\
\text { Vol(rwmd) }\end{array}$ \\
\hline tariff & $\begin{array}{l}0.000 \mathrm{~A} \\
2.00)^{* *}\end{array}$ & $\begin{array}{l}-0.000 \mathrm{~A} \\
(0.66)\end{array}$ & $\begin{array}{l}-0.000 \mathrm{~A} \\
(1.62)\end{array}$ & $\begin{array}{l}-0.000 \mathrm{~A} \\
(0.75)\end{array}$ & $\begin{array}{l}0.000 \mathrm{~A} \\
(0.09)\end{array}$ & $\begin{array}{l}-0.000 \mathrm{~A} \\
(0.92)\end{array}$ \\
\hline Vol(out) & $\begin{array}{l}.789 \\
11.26)^{* * *}\end{array}$ & $\begin{array}{l}0.110 \\
(2.89)^{* * *}\end{array}$ & $\begin{array}{l}0.126 \\
(3.00)^{* * *}\end{array}$ & $\begin{array}{l}0.608 \\
(7.32)^{* * *}\end{array}$ & $\begin{array}{l}0.063 \\
(1.18)\end{array}$ & $\begin{array}{l}0.060 \\
(0.99)\end{array}$ \\
\hline Vol(out)*tariff & $\begin{array}{l}0.002 \\
2.83)^{* * * *}\end{array}$ & $\begin{array}{l}0.000 \mathrm{~A} \\
(1.32)\end{array}$ & $\begin{array}{l}0.001 \\
(1.99)^{* *}\end{array}$ & $\begin{array}{l}-0.000 \mathrm{~A} \\
(0.25)\end{array}$ & $\begin{array}{l}0.000 \mathrm{~A} \\
(0.75)\end{array}$ & $\begin{array}{l}0.001 \\
(1.52)\end{array}$ \\
\hline Observations & 45 & 545 & 545 & 544 & 544 & 544 \\
\hline R-squared & .61 & 0.32 & 0.42 & 0.65 & 0.21 & 0.34 \\
\hline
\end{tabular}

Notes. Absolute value of $\mathrm{t}$ statistics in parentheses. $\left(^{*}\right)$ significant at $10 \%$ level; $\left({ }^{* *}\right)$ significant at $5 \%$ level; $(* * *)$ significant at $1 \%$ level. (A) Estimate is zero to the third decimal place. 